\title{
Liquid State and Zombie Dye Sensitized Solar Cells with Copper Bipyridine Complexes Functionalized with Alkoxy Groups
}

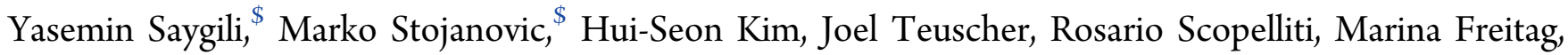
Shaik M. Zakeeruddin, Jacques-E. Moser, Michael Grätzel, and Anders Hagfeldt*

Cite This: J. Phys. Chem. C 2020, 124, 7071-7081

Read Online

ACCESS

Llll Metrics \& More

Article Recommendations

Supporting Information

ABSTRACT: Copper redox mediators can be employed in dye sensitized solar cells (DSCs) both as liquid electrolytes or as solid state hole transport materials (HTMs). The solid state devices that employ copper complex HTMs can be simply obtained by solvent evaporation in liquid state devices. During this evolution, the copper complex molecules present in the electrolyte solvent slowly aggregate in the pores of the $\mathrm{TiO}_{2}$ film and also close the gap between the $\mathrm{TiO}_{2}$ film and counter electrode. However, the crystallization of the HTM that infiltrated in the mesoscopic $\mathrm{TiO}_{2}$ pores can lead to low photovoltaic performance. In order to prevent this problem, we designed two copper redox

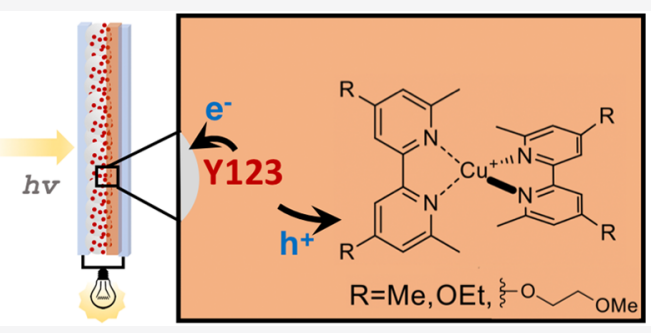
mediators $\left[\mathrm{Cu}(\text { beto })_{2}\right]^{1+}$ (beto $=4,4^{\prime}$-diethoxy-6,6 $6^{\prime}$-dimethyl-2,2'-bipyridine) and $\left[\mathrm{Cu}\left(\text { beto }_{2 \mathrm{Ox}}\right)_{2}\right]^{1+}\left(\right.$ beto $_{2 \mathrm{Ox}}=4,4^{\prime}$-bis $(2$ methoxyethoxy)-6,6'-dimethyl-2,2'-bipyridine) with extended side chains. First, we studied these complexes in liquid state devices in reference to the $\left[\mathrm{Cu}(\mathrm{tmby})_{2}\right]^{2+/ 1+}$ complex (tmby $=4,4^{\prime}, 6,6^{\prime}$ - tetramethyl-2,2' -bipyridine). The solar-to- electrical power conversion efficiencies for liquid state devices were over $10 \%$ for all of the complexes by using the organic Y 123 dye under 1000 $\mathrm{Wm}^{-2}$ AM1.5G illumination. However, solid state devices showed significantly diminished charge transport properties and short circuit current density values even though the crystallization was reduced.

\section{INTRODUCTION}

Dye-Sensitized Solar Cells (DSCs) show promising potential as third generation photovoltaic (PV) technologies. ${ }^{1,2}$ They offer energetically friendly fabrication processes in comparison to the silicon PV technology, and also satisfy aesthetic concerns. The employment of colored semitransparent glass and/or flexible substrates allows the easy integration of DSCs in buildings and electronic devices. ${ }^{5,6}$ Recently, Cao et al. reported astonishing results for indoor light applications of DSCs with power conversion efficiency (PCE) values exceeding $32 \%{ }^{7}$ The outstanding PCE values under ambient lightning makes DSC technology a favorable candidate to power low capacity portable electronic devices. ${ }^{8}$

The first DSC employing a ruthenium dye adsorbed on a mesoporous $\mathrm{TiO}_{2}$ electrode and iodide/triiodide electrolyte was reported in 1991, with 7\% PCE value under standard AM1.5G illumination. ${ }^{9}$ Since then, many efforts have been made for developing new dyes, ${ }^{10-14}$ electrolytes for liquid state devices, ${ }^{15-18}$ and hole transport materials ${ }^{19}$ (HTMs) for solidstate DSCs (ssDSCs) in order to advance the technology and increase the photovoltaic performance. With regard to electrolyte development, the replacement of the iodide/ triiodide redox couple with organometallic redox shuttles has resulted in significant ameliorations. With organometallic redox shuttles, i.e., cobalt and copper complexes, dye regeneration is satisfied with a simple one electron transfer process following Marcus Theory, ${ }^{20,21}$ whereas iodide/ triiodide follows a more complicated dye regeneration process. In addition, with metal complexes, the driving force for dye regeneration can be reduced significantly, hence an impressive improvement of the open circuit voltage $\left(V_{\mathrm{OC}}\right)^{22,23}$ while keeping a sufficient photocurrent ${ }^{21,24,25}$ is feasible. These metal complex redox mediators showed their compatibility with a wide library of $\mathrm{D}-\pi-A / \mathrm{D}-\mathrm{A}-\pi-A^{26-29}$ organic dyes. For ssDSCs, HTMs exist in a huge variety of inorganic and organic compounds. ${ }^{19}$ Some of the common HTMs (and corresponding PCE values reported) for ssDSCs can be exemplified as $\mathrm{CuSCN}(2 \%),{ }^{30} \mathrm{CuI}(4.5 \%),{ }^{31}$ poly $(3,4-$ ethylenedioxythiophene (PEDOT) (7.1\%), ${ }^{32} 2,2^{\prime}, 7,7^{\prime}$-tetrakis(N,N-di-p-methoxyphenylamine)-9,9' -spirobifluorene (spiroMeOTAD) $(7.7 \%),{ }^{33}$ and $\left.\mathrm{Cs}_{2} \mathrm{SnI}_{6}(7.8 \%)\right)^{34}$

Surprisingly, in 2015, Freitag et al. reported the so-called "zombie cells", 35 by employing a $\left[\mathrm{Cu}(\mathrm{dmp})_{2}\right]^{2+/ 1+}(\mathrm{dmp}=$ bis(2,9-dimethyl-1,10-phenantroline) redox mediator in DSCs. These ssDSCs were obtained simply by evaporating the volatile solvent from the liquid state DSC devices employing the $\left[\mathrm{Cu}(\mathrm{dmp})_{2}\right]^{2+/+}$ electrolyte. With the slow evaporation of

Received: January 24, 2020

Revised: $\quad$ March 9, 2020

Published: March 9, 2020 


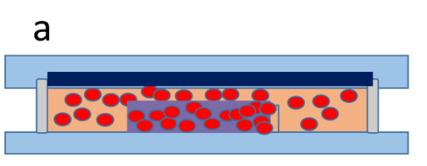

C

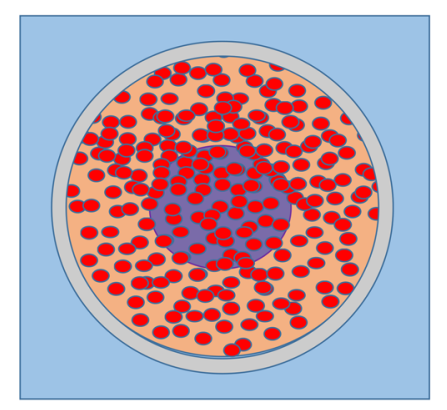

e

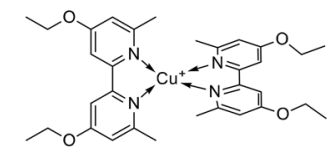

f

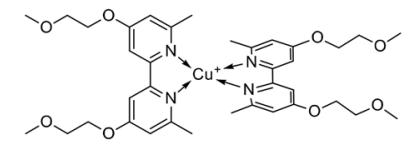

b

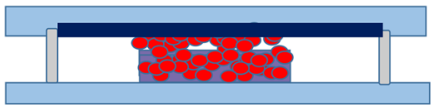

d

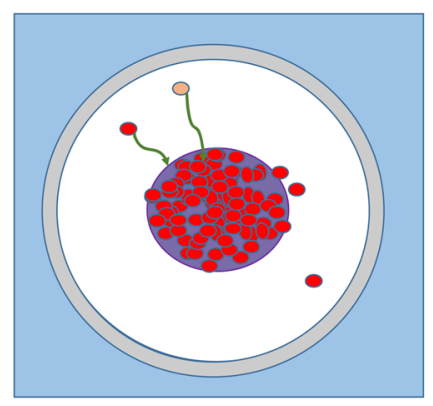

Dye sensitized $\mathrm{TiO}_{2}$ film

Copper complexes

Solvent

Surlyn encapsulation Glass substrates

PEDOT

Figure 1. Schematic representations of liquid state DSC (a) side (c) top views and zombie device (b) side (d) top views, and molecular structures of $(\mathrm{e})\left[\mathrm{Cu}(\text { beto })_{2}\right]^{2+/ 1+}$, (f) $\left[\mathrm{Cu}\left(\text { beto }_{2 \mathrm{Ox}}\right)_{2}\right]^{2+/ 1+},(\mathrm{g}) \mathrm{Y} 123$ dye.

the solvent molecules, the copper species aggregated throughout the pores of $\mathrm{TiO}_{2}$ and the $\mathrm{TiO}_{2}$-counter electrode gap. These aggregated copper redox mediators function as a HTM (Figure 1a-d). Similarly, Kashif et al. reported solutionprocessable HTMs with cobalt polypyridyl complexes. ${ }^{36}$ Later on, impressive PCEs of over $11 \%$ were reported for solid-state DSCs by employing $\left[\mathrm{Cu}(\text { tmby })_{2}\right]^{2+/ 1+}\left(\right.$ tmby $=4,4^{\prime}, 6,6^{\prime}-$ tetramethyl-2,2' -bipyridine) as a HTM. ${ }^{37,38}$ An argument for the higher efficiencies with the $\mathrm{Cu}$-complexes compared to those of other solid HTMs is that conventional ssDSCs, such as spiro-MeOTAD, suffer from the problems of inadequate pore filling. ${ }^{39}$ The spin-coated HTMs result in low pore filling through the mesoscopic semiconductor. For example, for a 2.5 $\mu \mathrm{m}$ thick $\mathrm{TiO}_{2}$ film, only $60-65 \%$ of the pores can be filled ${ }^{39}$ via spin-coating. With this recent progress on the fabrication of solid-state DSCs with copper redox mediators, ${ }^{35,37,38}$ thicker $\mathrm{TiO}_{2}$ films can be employed and accordingly, better light harvesting is possible.

Crystallization $^{40}$ of the HTM is also reported to be detrimental to the performance of ssDSCs. The solid-state copper HTM can also exhibit morphological variations affecting the reproducibility and performance of the devices. Kovalevsky et al. $^{41}$ emphasized the importance of packing forces in crystalline environment for solid state $\left[\mathrm{Cu}(\mathrm{dmp})_{2}\right]^{1+}$. Depending on the type of counterion, stacking interactions of the counterions and stacking modes of the ligands can show diversity, and $\left[\mathrm{Cu}(\mathrm{dmp})_{2}\right]^{1+}$ can exhibit polymorphic modifications and/or cocrystallization with solvent molecules. According to the pioneering work of Freitag et al., ${ }^{35}$ copper HTMs reveal a partially crystalline structure and a significant part of the HTM is in an amorphous state with the $\left[\mathrm{Cu}(\mathrm{dmp})_{2}\right]^{2+/ 1+}$ complex in ssDSCs. For $\left[\mathrm{Cu}(\mathrm{tmby})_{2}\right]^{2+/ 1+}$, Cao et al. ${ }^{37}$ reported that in some devices, the crystalline phase was observed and that holes can be trapped at crystal grain boundaries. Crystallization of the HTM inside the porous structure and at the interfaces hinders the hole transport. Therefore, the short circuit current density $\left(J_{\mathrm{SC}}\right)$ values are influenced negatively especially with increasing light intensities. Thus, it is reported that an amorphous phase is preferred for better performances of the cell.

The morphology of HTM can be tuned by modifying the structure of the ligands of the copper complexes. Especially, introduction of aliphatic side chains on the ligand and introduction of an asymmetric ligand in the complex can help to reduce lattice packing and hence the crystallinity. Accordingly, in this study, we designed two new copper complexes by keeping the $6,6^{\prime}$-dimethyl-2,2' -bipyridine scaffold, which proved to be efficient at stabilizing $\mathrm{Cu}(\mathrm{I}),{ }^{42,43}$ and by functionalizing the $4,4^{\prime}$ position with various side chains. With the introduction of $\left.[\mathrm{Cu} \text { (beto })_{2}\right]^{1+}$ (beto $=4,4^{\prime}$-diethoxy$6.6^{\prime}$-dimethyl-2,2'-bipyridine $)$ and $\left[\mathrm{Cu}\left(\text { beto }_{2 \mathrm{Ox}}\right)_{2}\right]^{1+}\left(\right.$ beto $_{2 \mathrm{Ox}}=$ 4,4'-bis(2-methoxyethoxy)-6,6'-dimethyl-2,2' -bipyridine) complexes, we aimed to hinder the crystallization at the interfaces of zombie devices through implementation of two different type of side chains at the $4,4^{\prime}$ positions. In regards to the aforementioned elements, we report the synthesis, characterization, as well as photovoltaic performances of new redox active copper complexes for both liquid and zombie DSCs. The chemical structures of the $\left.[\mathrm{Cu} \text { (beto })_{2}\right]^{1+}$ and $\left[\mathrm{Cu}\left(\text { beto }_{2 \mathrm{Ox}}\right)_{2}\right]^{1+}$ are given in Figure 1e,f, respectively. In liquid state devices, DSCs employing the new copper redox mediators reached PCE values higher than $10 \%$ under full sunlight illumination (AM 1.5G) by showing similar characteristics to the reference complex $\left[\mathrm{Cu}(\text { tmby })_{2}\right]^{2+/ 1+}$ with the $\mathrm{Y} 123$ dye (Figure 1g). The X-ray diffraction (XRD) measurements on the solid-state DSCs showed that the introduction of the 
aliphatic side chains (ethoxy and methoxyethoxy) to the ligands helped to reduce HTM crystallinity. However, the solidified versions of the new complexes resulted in very low PCE values. As observed by electrochemical impedance spectroscopy (EIS) and conductivity measurements, the charge transport ability of the HTMs decreased significantly. Diminished charge transport properties bring about the problems of reduced $J_{\mathrm{SC}}, V_{\mathrm{OC}}$ values, and hysteresis.

\section{EXPERIMENTAL SECTION}

Synthesis of Ligands. The synthesis of the ligands was performed by reacting the commercially available $4,4^{\prime}$ dibromo-6,6'-dimethyl-2,2'-bipyridine with an excess of alcohol precursor previously treated by 3 equivalents of sodium hydride $(\mathrm{NaH})$ at $90{ }^{\circ} \mathrm{C}$ overnight. The mixture was then poured over ice, and the ligands were extracted with dichloromethane (DCM) and subsequently dried to give the targeted structures: 4,4' -diethoxy-6.6' ${ }^{\prime}$-dimethyl-2,2' $2^{\prime}$-bipyridine (beto) and 4,4'-bis(2-methoxyethoxy)-6,6' -dimethyl-2,2' -bipyridine $\left(\right.$ beto $\left._{2 \mathrm{O}_{\mathrm{x}}}\right)$. The detailed synthetic procedure as well as characterization can be found in the Supporting Information.

Synthesis of Copper Complexes. The copper complexes were produced as previously reported. ${ }^{25,35,44}$ In order to produce $\mathrm{Cu}(\mathrm{I})$ species, one equivalent of $\mathrm{CuI}$ was mixed with four equivalents of ligand in ethanol, under an inert atmosphere at room temperature. After $2 \mathrm{~h}$, four equivalents of LiTFSI was added to the solution and mixing was continued for an additional $2 \mathrm{~h}$. The red/orange $\mathrm{Cu}(\mathrm{I})$ powder was collected by filtering the stirred solution and washed with water and diethyl ether. The $\mathrm{Cu}$ (II) complexes were obtained by the addition of $\mathrm{NOBF}_{4}$ to the electrolyte (direct oxidization of $\mathrm{Cu}(\mathrm{I})$ species). The details of the synthetic procedures are provided in Supporting Information.

Electrochemical Characterization. For cyclic voltammetry measurements, a three electrode setup was used, with a $\mathrm{Ag}$ / $\mathrm{AgCl} /$ saturated $\mathrm{LiCl}$ (ethanol) as reference electrode and platinum counter and working electrodes. The supporting electrolyte was a solution of $0.1 \mathrm{M}$ LiTFSI or $0.1 \mathrm{M}$ tetra- $n$ butylammonium hexafluorophosphate in acetonitrile. The concentrations of the $\left[\mathrm{Cu}(\text { beto })_{2}\right]^{1+}$ and $\left[\mathrm{Cu}\left(\text { beto }_{2 \mathrm{Ox}}\right)_{2}\right]^{1+}$ were 5.2 and $1.6 \mathrm{mM}$, respectively, and the scan rate was kept as 10 $\mathrm{mV} / \mathrm{s}$ for each measurement. The measurements were carried out by Autolab Pgstat-30 potentiostat. The formal potential of the in situ $\mathrm{Fc} / \mathrm{Fc}^{+}$couple was between 0.459 and $0.501 \mathrm{~V}$ vs our $\mathrm{Ag} / \mathrm{AgCl}$ reference electrodes $\left(\mathrm{Fc}^{+} / \mathrm{Fc}\right.$ versus $\mathrm{SHE}$ (Standard Hydrogen Electrode) value is taken as $+0.624 \mathrm{~V}){ }^{45}$

$\mathrm{UV} /$ vis absorption data for the copper complexes were gathered by a Hewlett-Packard 8453 diode array spectrometer. The extinction coefficients were calculated using the LambertBeer Law.

Single Crystal X-ray Diffraction. Single clear pale orange plate-shaped crystals of $\mathrm{Cu}$ (beto) $)_{2}$ TFSI were obtained by recrystallization from slow evaporation of an acetonitrile solution. A suitable crystal $0.67 \times 0.38 \times 0.21 \mathrm{~mm}^{3}$ was selected and mounted on a suitable support on a SuperNova, Dual, $\mathrm{Cu}$ at home/near, AtlasS2 diffractometer. The crystal was kept at a steady $T=140.00(10) \mathrm{K}$ during data collection. The structure was solved with the ShelXT (Sheldrick, 2015) structure solution program using the dual solution method and by using Olex2 (Dolomanov et al., 2009) as the graphical interface. The model was refined with version 2018/3 of ShelXL (Sheldrick, 2015) using Least Squares minimization.
X-ray Diffraction. X-ray diffraction (XRD) was measured by Empyrean (Panalytical) equipped with PIXel ${ }^{1 \mathrm{D}}$ (Panalytical) and a ceramic tube with $\mathrm{Cu}$ anode $(\lambda=1.54060 \AA)$. Samples for XRD measurements were obtained by removing the PEDOT counter electrode of ss-DSCs or drop-casting of electrolytes on top of $\mathrm{TiO}_{2}$ working electrode $\left(\mathrm{FTO} / \mathrm{TiO}_{2} /\right.$ Y123 substrates).

Device Fabrication. The working electrodes were prepared on cleaned FTO glasses (NSG-10, Nippon Sheet Glass). (The substrates were cleaned with a detergent (Deconex) in ultrasonic bath, and then treated with $\mathrm{UV} / \mathrm{O}_{3}$ (model no.256-220, Jelight Company, Inc.)) The $\mathrm{TiO}_{2}$ underlayer was grown with a chemical bath deposition of $\mathrm{TiCl}_{4}(53 \mathrm{mM})$. The mesoporous $\mathrm{TiO}_{2}$ is obtained by screen printing $30 \mathrm{NRD}$ (Dyesol) and scattering $\mathrm{TiO}_{2}$ pastes $(400 \mathrm{~nm}$ particle sized $)$ as transparent $(3 \mu \mathrm{m})$ and scattering layers $(3$ $\mu \mathrm{m})$, respectively. The films were sintered with a ramped temperature profile, by keeping the substrates at 125, 250, 370, 450 , and $500{ }^{\circ} \mathrm{C}$ for $5,5,5,15$, and $15 \mathrm{~min}$, respectively, with a 5 min ramping duration between each temperature.

Following a sintering process at $500{ }^{\circ} \mathrm{C}$ for $30 \mathrm{~min}$, the working electrodes were dipped into $0.1 \mathrm{mM}$ of dye solutions (Dyenamo $\mathrm{AB})$ in tert-butanol/acetonitrile $(1: 1 \mathrm{v} / \mathrm{v})$ mixture for $16 \mathrm{~h}$. In order to prevent aggregation, $0.4 \mathrm{mM}$ chenodeoxycholic acid was used in the dye solutions.

The PEDOT counter electrodes were prepared by electrodeposition on FTO glasses (TEC 6, Pilkington). ${ }^{46}$ Working and counter electrodes were assembled with melting a $25 \mu \mathrm{m}$ Surlyn spacer (Dupont). For $\left[\mathrm{Cu}\left(\text { beto }_{2 \mathrm{Ox}}\right)_{2}\right]^{2+/ 1+}$, the electrolyte solutions contained $0.2 \mathrm{M} \mathrm{Cu}(\mathrm{I})$ and $0.05 \mathrm{M} \mathrm{Cu}(\mathrm{II})$ species, $0.1 \mathrm{M}$ LiTFSI, and 0.6 M TBP in acetonitrile injected to the device through a predrilled hole by a vacuum pump. (Due to lower solubility of $\left.[\mathrm{Cu} \text { (beto })_{2}\right]^{2+/ 1+}$ in acetonitrile, the beto electrolyte is more diluted and contains $0.07 \mathrm{M} \mathrm{Cu}(\mathrm{I})$ and $0.02 \mathrm{M} \mathrm{Cu}$ (II) species.) A detailed device fabrication method can be found in our previous publication. ${ }^{25}$

Transient Absorption Spectroscopy (TAS). The photoinduced kinetics was measured with an Ekspla NT-342 Qswitched Nd:YAG laser using $532 \mathrm{~nm}$ as excitation wavelength. The pulse width was 4-5 ns (fwhm), and the repetition rate was $20 \mathrm{~Hz}$. The probe light source was a halogen lamp, and the probe wavelength at $715 \mathrm{~nm}$ was chosen using a monochromator. The film was positioned at approximately 45 degree angle with respect to the incoming laser pulse, for front illumination. The signal was detected using the photomultiplier tube R9110 from Hamamatsu and recorded using the oscilloscope DPO 7254 from Tektronix. The radiant output of the laser was attenuated using gray optical density filters to $46 \mu \mathrm{J} / \mathrm{cm}^{2}$, for the measurements of the samples containing redox mediators, and $1.27 \mu \mathrm{J} / \mathrm{cm}^{2}$ for the electrolytically inert samples. Low light intensity value was deliberately chosen in order to ensure that the data could be fitted to single exponential functions from which the lifetimes could be obtained. An acquisition was averaged over 3000 laser shots.

Electron Lifetime and Charge Extraction Measurements. DYENAMO Toolbox System was used to collect the electron lifetimes and charge extraction data. The Toolbox setup consists of a white LED light source (Seoul Semiconductors), a 16-bit resolution digital acquisition board (National Instruments), and a current amplifier (Thorlabs PDA200C). Prior to charge extraction, the DSCs were kept at open-circuit conditions and illuminated by the LED light. After $1 \mathrm{~s}$, the light source was turned off and the device was switched 
to short-circuit condition. Then the total extracted charge was integrated over time. In order to obtain a complete chargepotential curve, the measurement was repeated at different light intensities. In electron lifetime measurements, the light source was controlled by a modulated current superimposed on a bias current and the open-circuit voltage response was measured. The lifetimes were obtained by fitting parameters of open-circuit voltage response curves.

Solar Cell Characterization. The current-voltage $(I-V)$ performances of the DSC devices were obtained by using a 450W xenon light source (Oriel, U.S.A). Schott K113 Tempax filter (Präzisions Glas \& Optik $\mathrm{GmbH}$ ) was used to reduce the spectral mismatches between AM 1.5G and the light source. A Keithley model 2400 digital source meter (Keithley, U.S.A) was used to apply an external potential bias to the devices and measure the resulting current. For $I-V$ measurements, we used a black mask with a $0.16 \mathrm{~cm}^{2}$ aperture area.

Incident Photon to Current Conversion Efficiency (IPCE). IPCE data were acquired using a computer controlled setup consisting of a $300 \mathrm{~W}$ xenon light source (ILC Technology, USA), a monochromator (JobinYvon Ltd., UK), and a Keithley 2700 multimeter.

Electrochemical Impedance Spectroscopy (EIS). BioLogic SP300 potentiostat was used to carry out impedance measurements. A sinusoidal potential perturbation was applied within a frequency range of $7 \mathrm{MHz}-0.1 \mathrm{~Hz}$. The bias potential was manipulated between $0 \mathrm{~V}$ and $V_{\mathrm{OC}}$, with $50 \mathrm{mV}$ increments. The impedance data was fitted with ZView software (Scribner Associates) according to the transmission line method. ${ }^{47}$

Conductivity. Two channel conductivity measurements were performed by using NanoSPR interdigitated electrodes. The electrolyte solutions were deposited on the electrodes by drop-casting. The current-potential data was gathered by a BioLogic SP30 potentiostat.

\section{RESULTS AND DISCUSSION}

Spectroscopic and Electrochemical Characterization. The UV/vis spectra of $\left.[\mathrm{Cu} \text { (beto })_{2}\right][\mathrm{TFSI}]$ and $[\mathrm{Cu}$ $\left.\left(\text { beto }_{2 \mathrm{Ox}_{\mathrm{x}}}\right)_{2}\right][\mathrm{TFSI}]$ were recorded with a $0.5 \mathrm{mM}$ acetonitrile solution of each complex. The absorbance measurements showed that both complexes have very similar spectral responses. Two local absorption maxima were found, lying around 334 and $440 \mathrm{~nm}$ for both $\left.[\mathrm{Cu} \text { (beto) })_{2}\right]$ [TFSI] and $\left[\mathrm{Cu}\left(\text { beto }_{2 \mathrm{Ox}}\right)_{2}\right][\mathrm{TFSI}]$ (see Figure S1). The first peak, is attributed to a $\pi-\pi^{*}$ transition, originating from the $2,2^{\prime}$ bipyridine ligand conjugated network. Here, it is reasonable to assume that the wavelength at which the transition will occur will be influenced by the electronic substituents located on the $2,2^{\prime}$-bipyridine scaffold. In this case, both complexes showed a transition occurring at $334 \mathrm{~nm}$. This would indicate that there is not a major influence on the electronic properties arising from the ether chain present in $\left[\mathrm{Cu}\left(\text { beto }_{2 \mathrm{Ox}}\right)_{2}\right][\mathrm{TFSI}]$. The second electronic transition occurs around $440 \mathrm{~nm}$ for both complexes and is attributed to a metal to ligand charge transfer transition (MLCT), which also seems to indicate similar photophysical properties between $\left[\mathrm{Cu}(\text { beto })_{2}\right][\mathrm{TFSI}]$ and $\left[\mathrm{Cu}\left(\text { beto }_{2 \mathrm{Ox}}\right)_{2}\right][\mathrm{TFSI}]$. The molar extinction coefficients were calculated and are reported in Table 1. They show similar values for both complexes for each discussed transition.

Cyclic voltammetry was used to probe the electrochemical activity of the newly synthesized complexes. As presented in Table 1 and Figure S2, the redox potentials of our complexes
Table 1. Absorption Data and Formal Redox Potentials of the $\mathrm{Cu}(1)$ Complexes

\begin{tabular}{lccccc}
$\begin{array}{ll}{\left[\mathrm{Cu}(\mathrm{L})_{2}\right]} \\
{[\mathrm{TFSI}]}\end{array}$ & $\begin{array}{c}\lambda_{\pi-\pi^{*}} / \\
\mathrm{nm}\end{array}$ & $\begin{array}{c}\varepsilon^{-1} \times \pi^{*} / \\
\mathrm{Mcm}^{-1}\end{array}$ & $\begin{array}{c}\lambda_{\mathrm{MLCT}} / \\
\mathrm{nm}\end{array}$ & $\begin{array}{c}\varepsilon_{\mathrm{MLCT}} / \\
\mathrm{M}^{1} \times \mathrm{cm}^{-1}\end{array}$ & $\begin{array}{c}\mathrm{E}^{0} /(\mathrm{V} \mathrm{vs} \\
\mathrm{SHE})\end{array}$ \\
$\mathrm{L}=$ beto & 334 & $4.88 \times 10^{3}$ & 443 & $5.02 \times 10^{3}$ & 0.79 \\
$\mathrm{~L}=$ beto $_{2 \mathrm{Ox}}$ & 334 & $5.33 \times 10^{3}$ & 440 & $5.25 \times 10^{3}$ & 0.81 \\
\hline
\end{tabular}

are around $0.8 \mathrm{~V}$ vs SHE. This shows similar electrochemical properties between the two complexes but also indicates that the ether chain present on beto $_{20 x}$ does not alter its redox behavior. Our copper-complexes showed good electrochemical activity and reversibility upon several scans. In comparison to the unfunctionalized $\left[\mathrm{Cu}(\mathrm{dmby})_{2}\right]^{2+/ 1+}\left(\mathrm{dmby}=6,6^{\prime}\right.$-dimethyl-2,2'-bipyridine) complex, our ligands showed a downwardly shifted potential of approximately $0.2 \mathrm{~V}$ vs SHE. This effect is attributed to the $\pi$-electron donating oxygen atoms that were installed at the $4,4^{\prime}$ position of the ligands. They would increase the electron density of the copper center, via the ligand, hence increasing the reductive strength of the complex.

The state-of-the-art $\mathrm{Cu}\left[(\mathrm{tmby})_{2}\right]^{2+/ 1+}$ complex offers a redox potential of $0.871 \mathrm{~V}$ vs SHE, while other $2,2^{\prime}$-bipyridine or phenanthroline based ligands produce a redox potential above $0.9 \mathrm{~V}$ vs SHE. ${ }^{25}$ This limits the use of dyes with Highest Occupied Molecular Orbital (HOMO) levels that are more negative than $1 \mathrm{~V}$ vs SHE. (For example, $\mathrm{Y}_{123}{ }^{25}$ (1.07 V vs $\mathrm{SHE})$ and $\mathrm{XY}^{48}$ (0.99 V vs SHE) dyes showed compatibility with these redox mediators.) Considering the more negative formal redox potentials of $\left.[\mathrm{Cu} \text { (beto })_{2}\right]^{1+}$ and $\left[\mathrm{Cu}\left(\text { beto }_{20 x}\right)_{2}\right]^{1+}$ complexes, we can presume that for these complexes, the choice of suitable dyes is higher.

Single Crystal X-ray Diffraction. Crystals suitable for Xray diffraction were grown from slow evaporation at room temperature of an acetonitrile solution of $\left.[\mathrm{Cu} \text { (beto })_{2}\right][\mathrm{TFSI}]$. Unfortunately, this could not be achieved for $\left[\mathrm{Cu}\left(\text { beto }_{2 \mathrm{Ox}}\right)_{2}\right]$ [TFSI] even after screening of different solvents as well as binary solvent mixture conditions. We speculate that this is due to the ethoxy-methoxy chains located at the $4,4^{\prime}$ position of $\left[\mathrm{Cu}\left(\text { beto }_{2 \mathrm{Ox}}\right)_{2}\right][\mathrm{TFSI}]$ that would prevent an efficient molecular packing and hence crystallization of the molecule.

Figure 2 shows the ORTEP (Oak Ridge Thermal Ellipsoid Plot) representation of $\left[\mathrm{Cu}(\text { beto })_{2}\right][$ TFSI $]$ crystals. They

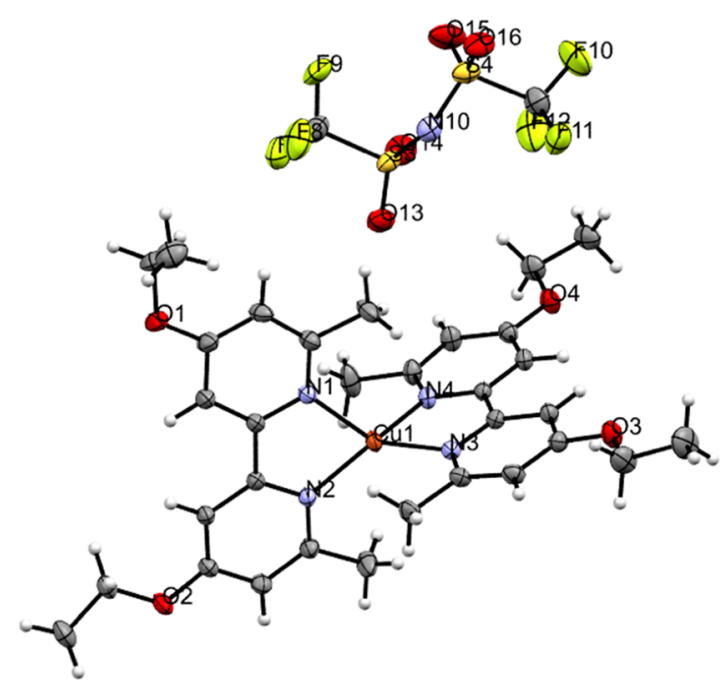

Figure 2. OTREP representation of $\left[\mathrm{Cu}(\text { beto })_{2}\right][\mathrm{TFSI}]$. 
essentially consist of isolated $\left[\mathrm{Cu}(\text { beto })_{2}\right]^{1+}$ with uncoordinated $\mathrm{TFSI}^{-}$anions. As expected, the bipyridine ligand coordinates the central copper atom in a bidentate mode. The two methyl groups at the $6,6^{\prime}$ position prevent the ligands from twisting, which ultimately stabilizes the coordination complex in a strongly distorted tetrahedral geometry. The measured coordinating bond lengths were consistent and very close to $2 \AA$ (see Table 2). There are three different sets of

Table 2. Crystallographic Data, Bond Lengths, and Angles of $\left.[\mathrm{Cu} \text { (beto })_{2}\right][$ TFSI $]$

\begin{tabular}{|c|c|c|c|}
\hline Molecular formula & $\mathrm{C}_{34} \mathrm{H}_{40} \mathrm{CuF}_{6} \mathrm{~N}_{5} \mathrm{O}_{8} \mathrm{~S}_{2}$ & & \\
\hline & & \multicolumn{2}{|c|}{ Bond Length/( $)$} \\
\hline $\mathrm{MW} /(\mathrm{g} / \mathrm{mol})$ & 888.37 & $\mathrm{Cu} 1-\mathrm{N} 1$ & 2.061 \\
\hline Crystal system & Monoclinic & $\mathrm{Cu} 1-\mathrm{N} 2$ & 2.011 \\
\hline Space group & $\mathrm{P} 2_{1} / n$ & $\mathrm{Cu} 1-\mathrm{N} 3$ & 2.040 \\
\hline $\mathrm{a} /(\AA)$ & $15.67850(11)$ & $\mathrm{Cu} 1-\mathrm{N} 4$ & 2.034 \\
\hline \multirow[t]{2}{*}{$\mathrm{b} /(\AA)$} & $23.18286(15)$ & & \\
\hline & & \multicolumn{2}{|c|}{ Angle/(deg) } \\
\hline c/( $\AA)$ & $21.81083(15)$ & $\mathrm{N} 1-\mathrm{Cu} 1-\mathrm{N} 2$ & 80.89 \\
\hline$\alpha /(\operatorname{deg})$ & 90 & $\mathrm{~N} 2-\mathrm{Cu} 1-\mathrm{N} 3$ & 132.26 \\
\hline$\beta /(\operatorname{deg})$ & $97.9481(7)$ & $\mathrm{N} 3-\mathrm{Cu} 1-\mathrm{N} 4$ & 80.94 \\
\hline$\gamma /(\operatorname{deg})$ & 90 & $\mathrm{~N} 4-\mathrm{Cu} 1-\mathrm{N} 1$ & 117.47 \\
\hline Cell Volume $/\left(\AA^{3}\right)$ & $7851.48(9)$ & $\mathrm{N} 2-\mathrm{Cu} 1-\mathrm{N} 4$ & 131.09 \\
\hline $\mathrm{Z}$ & 8 & $\mathrm{~N} 1-\mathrm{Cu} 1-\mathrm{N} 3$ & 118.62 \\
\hline
\end{tabular}

angles: the five membered ring chelate $(\mathrm{N} 1-\mathrm{Cu} 1-\mathrm{N} 2$ and $\mathrm{N} 3-\mathrm{Cu} 1-\mathrm{N} 4)$ was close to $81^{\circ}$ and two additional angles formed by the intercrossed ligand planes, $\mathrm{N} 4-\mathrm{Cu} 1-\mathrm{N} 1$ and $\mathrm{N} 1-\mathrm{Cu} 1-\mathrm{N} 3$, were around $118^{\circ}$, with $\mathrm{N} 2-\mathrm{Cu} 1-\mathrm{N} 4$ and $\mathrm{N} 2-\mathrm{Cu} 1-\mathrm{N} 3$ having values approaching $132^{\circ}$. Beside the five membered bidentate angles, the two other sets show strong fluctuation indicating an important distortion of the coordination geometry. The dihedral angle along the $2,2^{\prime}$ axis of the bipyridine shows very little torsion values of $3.12^{\circ}$ and $0.84^{\circ}$, respectively. Reported $\mathrm{Cu}(\mathrm{I})$ complexes were found to have similar geometrical trends upon coordination of $\mathrm{Cu}(\mathrm{I})$ with $6,6^{\prime}, 4,4^{\prime}$-tetramethyl-2,2' -biypridine or $6,6^{\prime}$-dimethyl-2,2' -biypridine ligands. ${ }^{49,50}$

X-ray Diffraction (XRD) Measurements. We analyzed the effect of the ligand structures of $\left.[\mathrm{Cu} \text { (beto })_{2}\right]^{2+/ 1+}$ and $\left[\mathrm{Cu}\left(\text { beto }_{2 \mathrm{Ox}}\right)_{2}\right]^{2+/ 1+}$ complexes on the morphology of the HTM by X-ray diffraction (XRD) measurements on the $\mathrm{FTO} / \mathrm{TiO}_{2} /$ Y123/HTM samples. The XRD data of the working electrodes of the opened DSC devices and the dried samples which were prepared by drop-casting are given in Figure $3 a, b$, respectively. As observed in Figure $3 \mathrm{a}$, the $\left[\mathrm{Cu}\left(\text { beto }_{2 \mathrm{Ox}}\right)_{2}\right]^{2+/ 1+}$ (blue) and $\left.[\mathrm{Cu} \text { (beto })_{2}\right]^{2+/ 1+}$ (red) do not exhibit any crystalline phases in zombie devices. As presumed, introduction of the aliphatic side chains (ethoxy and methoxyethoxy) reduced HTM crystallinity. The XRD pattern for the $\left[\mathrm{Cu}(\mathrm{tmby})_{2}\right]^{2+/ 1+}$ complex shows the presence of 12 and 24 degree peaks (black line in Figure $3 \mathrm{a}$ ), which are attributed to a partially crystalline phase. Drop-casting of the electrolyte solution provides a faster evaporation of the solvents, and the crystalline phase is expected to become more apparent. With the drop-casting method, for $\left[\mathrm{Cu}\left(\text { beto }_{2 \mathrm{Ox}}\right)_{2}\right]^{2+/ 1+}$, the amorphous phase is almost preserved by disregarding the low-lying peaks (red line in Figure $3 b)$. In case of the $\left.[\mathrm{Cu} \text { (beto })_{2}\right]^{2+/ 1+}$, the faster solvent evaporation results in a crystalline structure (blue line in Figure $3 \mathrm{~b})$, nonetheless, with less intense peaks in comparison to $\left[\mathrm{Cu}(\mathrm{tmby})_{2}\right]^{2+/ 1+}$ (Figure S3). When the XRD data is considered, it can be stated that the slow evaporation of the electrolyte solvent is still necessary to inhibit the crystalline HTM and the detrimental effects.

Dye Regeneration and Charge Recombination Analysis with Liquid Electrolytes. In order to investigate the dye regeneration kinetics with the $\left.[\mathrm{Cu} \text { (beto })_{2}\right]^{2+/ 1+}$ and $[\mathrm{Cu}-$ $\left.\left(\text { beto }_{2 \mathrm{Ox}}\right)_{2}\right]^{2+/ 1+}$ liquid electrolytes, we performed nanosecond transient absorption spectroscopy (TAS) measurements. The recombination of injected electrons in the $\mathrm{TiO}_{2}$ and oxidized dye molecules showed an absorbance decay signal with a 0.55 ms half-lifetime $\left(\tau_{1 / 2}\right)$ in the absence of redox species (only 0.1 $\mathrm{M}$ LiTFSI and 0.6 M TBP in acetonitrile) (see Figure 4). In the presence of our redox electrolyte, the absorbance signal
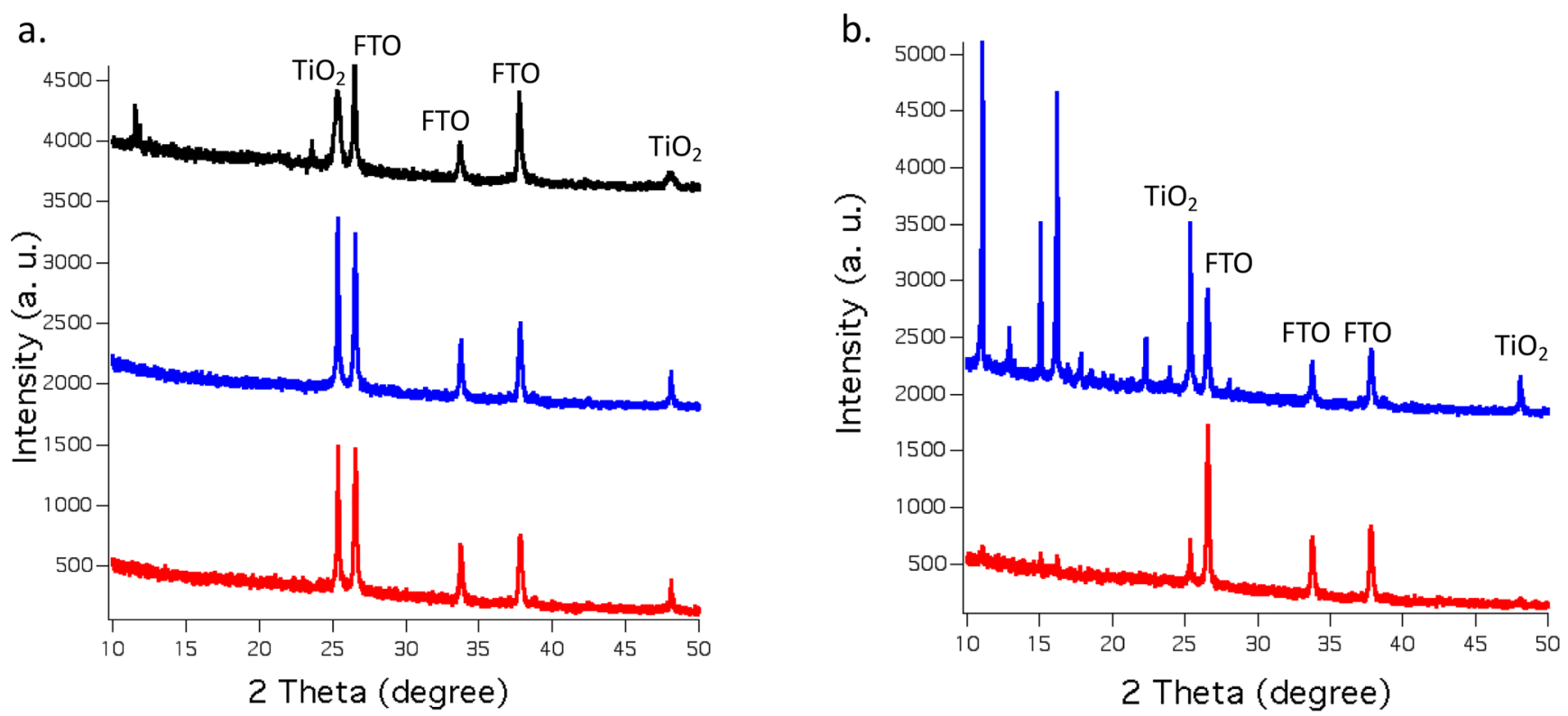

Figure 3. XRD data of (a) working electrode of opened ssDSC devices $\left(\mathrm{FTO} / \mathrm{TiO}_{2} / \mathrm{Y} 123 / \mathrm{HTM}\right)\left(\left[\mathrm{Cu}(\text { beto })_{2}\right]^{2+/ 1+}\left(\mathrm{blue}^{2}\right),\left[\mathrm{Cu}\left(\text { beto } 2 \mathrm{O}_{\mathrm{x}}\right)_{2}\right]^{2+/ 1+}\right.$ $($ red $)$, and $\left[\mathrm{Cu}(\text { tmby })_{2}\right]^{2+11+}($ black $\left.)\right)$. (b) Dried electrolytes after drop-casting $\left([\mathrm{Cu} \text { (beto })_{2}\right]^{2+/ 1+}$ (blue) and $\left[\mathrm{Cu}\left(\text { beto } \mathrm{b}_{2 \mathrm{x}}\right)_{2}\right]^{2+/ 1+}($ red $\left.)\right)$. 


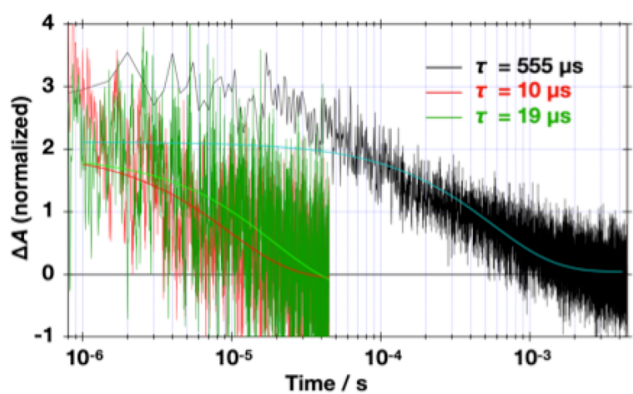

Figure 4. Transient absorption spectroscopy measurements of Y123sensitized $\mathrm{TiO}_{2}$ films with inert (black), $\left[\mathrm{Cu}\left(\text { beto }_{20 \mathrm{x}}\right)_{2}\right]^{2+/ 1+}($ red), $\left[\mathrm{Cu}(\text { beto })_{2}\right]^{2+/ 1+}$ (green) electrolytes.

shows an accelerated decay, which indicates the regeneration of oxidized dye molecules by $\mathrm{Cu}(\mathrm{I})$ species. Under the same conditions, the regeneration halftimes of $\left[\mathrm{Cu}(\text { beto })_{2}\right]^{2+/ 1+}$ and $\left[\mathrm{Cu}\left(\text { beto }_{2 \mathrm{Ox}}\right)_{2}\right]^{2+/ 1+}$ are measured as 19 and $10 \mu \mathrm{s}$, respectively. Using eq 1 , the regeneration efficiencies $\left(\Phi_{\text {reg }}\right)$ are calculated as $97 \%$ and $98 \%$ for the $\left.[\mathrm{Cu} \text { (beto })_{2}\right]^{2+/ 1+}$ and $[\mathrm{Cu}-$ $\left.\left(\text { beto }_{2 \mathrm{Ox}}\right)_{2}\right]^{2+/ 1+}$ complexes, respectively.

$$
\Phi_{r e g}=\frac{k_{r e g}}{k_{r e g}+k_{r e c}}
$$

In comparison to the previously reported [Cu$\left.(\text { tmby })_{2}\right]^{2+/ 1+}$ complex, $^{25}\left[\mathrm{Cu}(\text { beto })_{2}\right]^{2+/ 1+}$ and $[\mathrm{Cu}-$ $\left.\left(\text { beto }_{2 \mathrm{Ox}}\right)_{2}\right]^{2+/ 1+}$ have bulkier ligand structures with the substitution of ethoxy and methoxyethoxy groups. The differences in regeneration efficiencies can be attributed to the differences in molecular structures and reorganization energies of these three copper complexes. As expected, the spatial separation of the donor and acceptor states with the extended 4,4'-bis(2-methoxyethoxy) groups of [Cu$\left.\left(\text { beto }_{2 \mathrm{Ox}}\right)_{2}\right]^{2+/ 1+}$ and $4,4^{\prime}$-diethoxy groups of $\left[\mathrm{Cu}(\text { beto })_{2}\right]^{2+/ 1+}$ will be higher and the electron transfer rates will be slower compared to $\left[\mathrm{Cu}(\mathrm{tmby})_{2}\right]^{2+/ 1+}$ complex. Also, by considering the diffusional constraints of $\left[\mathrm{Cu}\left(\text { beto }_{2 \mathrm{Ox}}\right)_{2}\right]^{2+/ 1+}$ and $[\mathrm{Cu}-$ (beto) $\left.{ }_{2}\right]^{2+/ 1+}$ in the mesoporous $\mathrm{TiO}_{2}$ structure, smaller dye regeneration efficiency values are foreseen for the new complexes. Nevertheless, increased spatial separation and diffusion problems are compensated by the increased driving force for dye regeneration. Therefore, dye regeneration efficiencies stay closer to unity for $\left.[\mathrm{Cu} \text { (beto })_{2}\right]^{2+/ 1+}$ and
$\left[\mathrm{Cu}\left(\text { beto }_{2 \mathrm{Ox}_{\mathrm{x}}}\right)_{2}\right]^{2+/ 1+}$ complexes as in the case of $[\mathrm{Cu}-$ $\left.(\text { tmby })_{2}\right]^{2+/ 1+}$.

We analyzed the recombination of the oxidized form of the redox species and the injected electrons in $\mathrm{TiO}_{2}$ by electron lifetime and charge extraction measurements. The semilogarithmic plots of electron lifetime and charge extraction values with respect to the quasi-Fermi level of the electrons in $\mathrm{TiO}_{2}$ are given in Figure 5a,b, respectively. At the same quasiFermi level of electrons in the $\mathrm{TiO}_{2}$ electrode $(-0.2 \mathrm{eV})$, the electron lifetimes in the presence of $\left.[\mathrm{Cu} \text { (beto })_{2}\right]^{2+/ 1+}$, $\left[\mathrm{Cu}\left(\text { beto }_{2 \mathrm{Ox}}\right)_{2}\right]^{2+/ 1+}$, and $\left[\mathrm{Cu}(\text { tmby })_{2}\right]^{2+/ 1+}$ complexes are $0.08,0.03$, and $0.008 \mathrm{~s}$, respectively. By having a more positive redox potential and higher driving force for recombination, the $\left[\mathrm{Cu}(\text { tmby })_{2}\right]^{2+/ 1+}$ complex exhibits lower electron lifetime values due to higher recombination rates. These values show that the recombination reaction is driving force dependent similar to our previous studies. ${ }^{51}$

For the same extracted charge value, $\left[\mathrm{Cu}(\text { beto })_{2}\right]^{2+/ 1+}$ and $\left[\mathrm{Cu}\left(\text { beto }_{2 \mathrm{Ox}}\right)_{2}\right]^{2+/ 1+}$ exhibit a slightly negative shifted conduction bands in comparison to $\left[\mathrm{Cu}(\text { tmby })_{2}\right]^{2+/ 1+}$. This finding is attributed to a slightly more negative surface charge value for the $\left[\mathrm{Cu}(\text { beto })_{2}\right]^{2+/ 1+}$ and $\left[\mathrm{Cu}\left(\text { beto }_{2 \mathrm{Ox}}\right)_{2}\right]^{2+/ 1+}$ redox species. $\left.[\mathrm{Cu} \text { (beto })_{2}\right]^{2+/ 1+}$ and $\left[\mathrm{Cu}\left(\text { beto }_{2 \mathrm{Ox}}\right)_{2}\right]^{2+/ 1+}$ showed the same extracted charge values through the whole potential range.

Photovoltaic Performances of the DSC Devices Employing the Y123 Dye. The photocurrent densityvoltage $(J-V)$ data of solar cells prepared by Y123 sensitized $\mathrm{TiO}_{2}$ films that employed liquid state copper electrolytes are given in Figure 6a. The short-circuit current densities $\left(J_{\mathrm{sc}}\right)$, open circuit voltages $\left(V_{\mathrm{oc}}\right)$, fill factors $(\mathrm{FF})$, and power conversion efficiencies (PCEs) of these devices are also given in Table 3. The PCE values are calculated by eq 2 where $J_{s c}$ is the current density, $V_{\text {oc }}$ is the open circuit voltage, FF is fill factor, and $I_{0}$ is the incident light intensity.

$$
\eta=J_{s c} \times V_{o c} \times \frac{\mathrm{FF}}{I_{0}}
$$

For the liquid state devices employing $\left[\mathrm{Cu}(\mathrm{tmby})_{2}\right]^{2+/ 1+}$, $\left[\mathrm{Cu}\left(\text { beto }_{2 \mathrm{Ox}}\right)_{2}\right]^{2+/ 1+},\left[\mathrm{Cu}(\text { beto })_{2}\right]^{2+/ 1+}$, the PCE values above $10 \%$ were reached at AM $1.5 \mathrm{G}$ illumination. The open circuit voltage values are above $1.0 \mathrm{~V}$. The higher redox potential of the $\left[\mathrm{Cu}(\text { tmby })_{2}\right]^{2+/ 1+}$ complex would result in a higher photovoltage, but the longer electron lifetime for the new
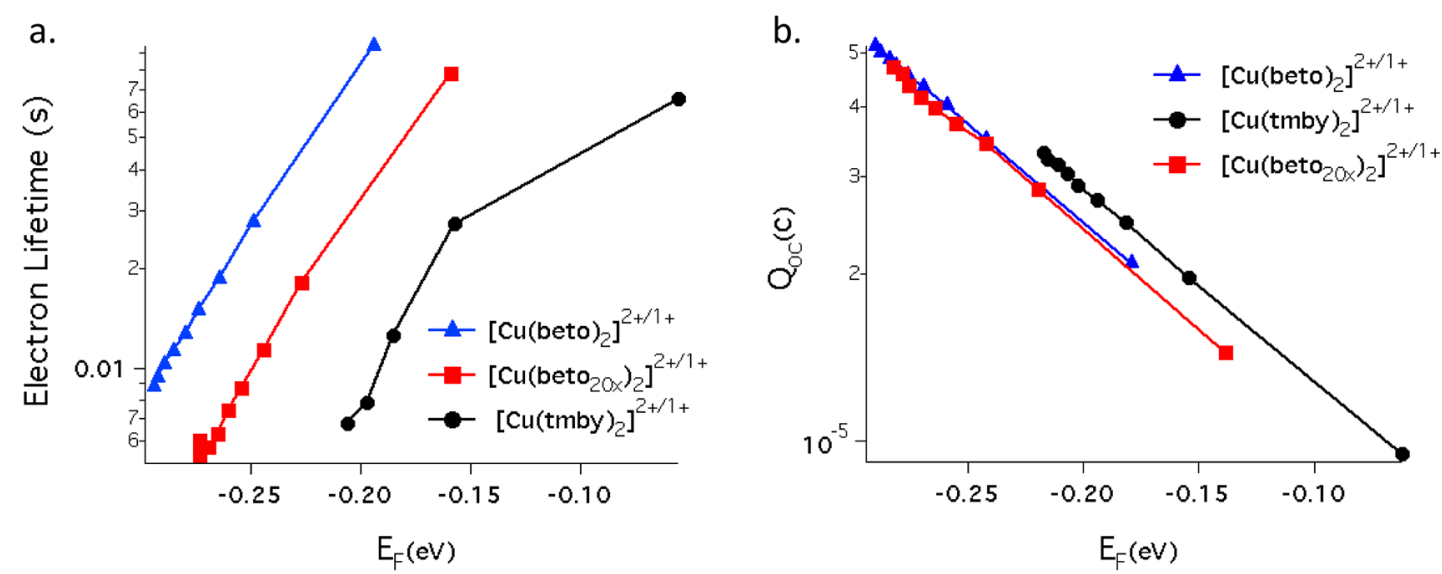

Figure 5. (a) Electron lifetime and (b) charge extraction values for the copper complexes. $\left(E_{\mathrm{F}, \mathrm{TiO} 2}=E_{\mathrm{F}, \mathrm{TiO} 2}-V_{\mathrm{oc}}\right)$. 

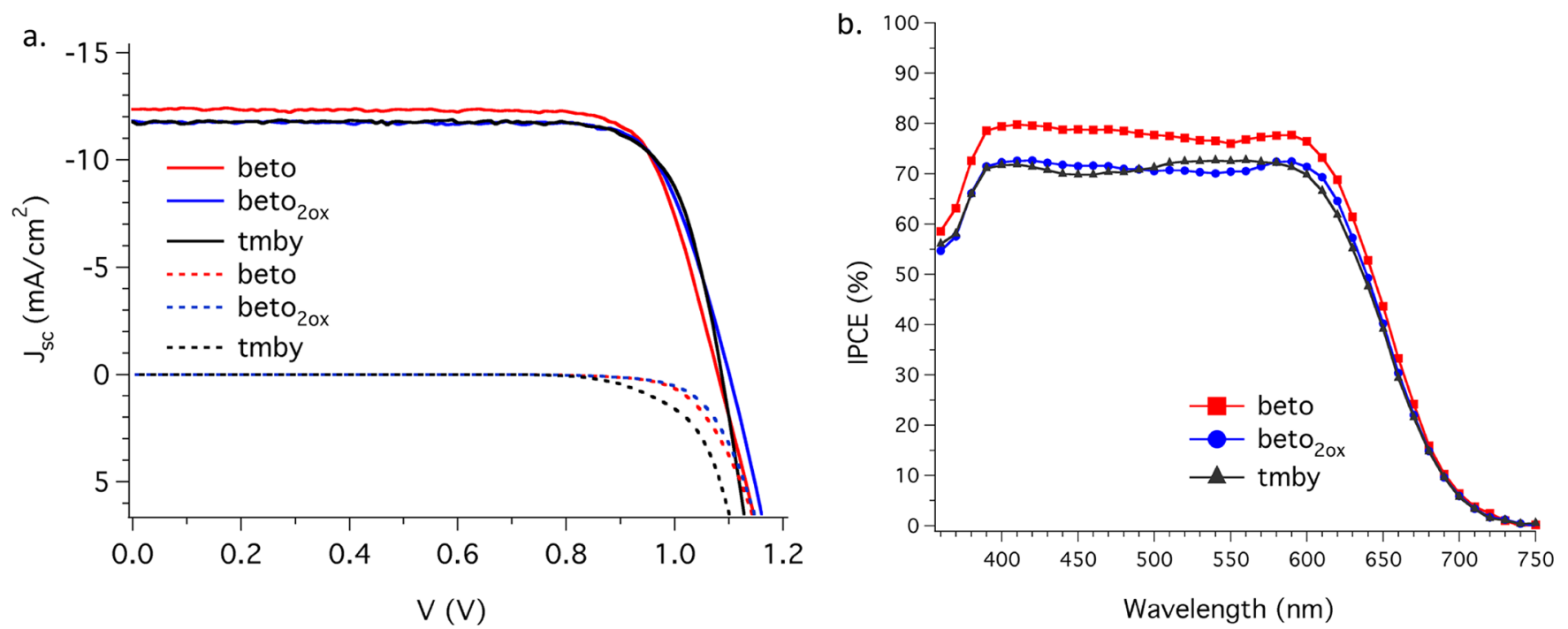

Figure 6. Photovoltaic characterization of the DSCs sensitized with $\mathrm{Y} 123$ dye employing $\left[\mathrm{Cu}(\mathrm{tmby})_{2}\right]^{2+/ 1+},\left[\mathrm{Cu}(\text { beto })_{2}\right]^{2+/ 1+}$, and $\left[\mathrm{Cu}\left(\text { beto }_{2 \mathrm{Ox}}\right)_{2}\right]^{2+/ 1+}$ electrolytes (a) Photocurrent density vs voltage data measured for solar cells sensitized with Y123 dye under standard AM $1.5 \mathrm{G}$ illumination and in the dark (b) IPCE spectra of the liquid state DSC devices sensitized with Y123 dye.

Table 3. $J-V$ characteristics for the liquid state devices employing $\left[\mathrm{Cu}(\mathrm{tmby})_{2}\right]^{2+/ 1+},\left[\mathrm{Cu}(\text { beto })_{2}\right]^{2+/ 1+}$ and $\left[\mathrm{Cu}\left(\text { beto }_{2 \mathrm{Ox}}\right)_{2}\right]^{2+/ 1+}$ complexes under standard AM 1.5G illumination

\begin{tabular}{lcccc}
\multicolumn{1}{c}{ Redox couple } & $\boldsymbol{V}_{\text {oc }}(\mathbf{V})$ & $\boldsymbol{J}_{\mathbf{s c}}\left(\mathbf{m A ~ c m} \mathbf{~ c m}^{-2}\right)$ & FF & PCE (\%) \\
{$\left[\mathrm{Cu}(\text { tmby })_{2}\right]^{2+/ 1+}$} & 1.087 & 11.815 & 0.786 & 10.06 \\
{$\left[\mathrm{Cu}(\text { beto })_{2}\right]^{2+/ 1+}$} & 1.08 & 12.392 & 0.781 & 10.42 \\
{$\left[\mathrm{Cu}\left(\text { beto }_{20 \mathrm{x}}\right)_{2}\right]^{2+/ 1+}$} & 1.01 & 11.851 & 0.783 & 10.18 \\
\hline
\end{tabular}

complex $\left[\mathrm{Cu}(\text { beto })_{2}\right]^{2+/ 1+}$ compensates for this, resulting in a very similar $V_{\text {oc }}$ for these complexes. The slightly higher shortcircuit current density obtained with the $\left[\mathrm{Cu}(\text { beto })_{2}\right]^{2+/ 1+}$ electrolyte is attributed to the slightly higher driving force available for dye regeneration and less parasitic absorption of the electrolyte due to lower solubility of $\mathrm{Cu}(\mathrm{I})$ species, confirmed by higher incident photon-to-current conversion efficiency (IPCE). The FF values stayed similar in liquid state DSCs with all the complexes.

The IPCE spectra for the liquid state devices employing $\left[\mathrm{Cu}(\text { beto })_{2}\right]^{2+/ 1+},\left[\mathrm{Cu}\left(\text { beto }_{2 \mathrm{Ox}}\right)_{2}\right]^{2+/ 1+}$, and $\left[\mathrm{Cu}(\text { tmby })_{2}\right]^{2+/ 1+}$ are given in Figure $6 \mathrm{~b}$. For the $\left.[\mathrm{Cu} \text { (beto })_{2}\right]^{2+/ 1+}$ electrolyte, the maximum IPCE is found at $400 \mathrm{~nm}$ as $80 \%$. For [Cu$\left.\left(\text { beto }_{2 \mathrm{Ox}}\right)_{2}\right]^{2+/ 1+}$ and $\left[\mathrm{Cu}(\text { tmby })_{2}\right]^{2+/ 1+}$ electrolytes, the IPCE maxima stayed around $70 \%$. The lower IPCE values for $\left[\mathrm{Cu}\left(\text { beto }_{2 \mathrm{Ox}}\right)_{2}\right]^{2+/ 1+}$ and $\left[\mathrm{Cu}(\text { tmby })_{2}\right]^{2+/ 1+}$ are attributed to the slightly higher parasitic absorptions of these electrolytes in comparison to that of $\left.[\mathrm{Cu} \text { (beto })_{2}\right]^{2+/ 1+}$, which has fewer copper species in the electrolyte (due to poor solubility) and therefore induces less parasitic absorption.

For the introduced new copper complexes, which exhibit poorer photovoltaic performance in the solid compared to the liquid state, typical JV data of the zombie devices prepared by Y123 sensitized $\mathrm{TiO}_{2}$ films that employ solid copper complex HTMs are given in Figure 7. The $J_{\mathrm{sc}} V_{\mathrm{oc}}, \mathrm{FF}$, and PCE of these devices are also given in Table 4. Contrary to the $[\mathrm{Cu}$ $\left.(\text { tmby })_{2}\right]^{2+/ 1+} \mathrm{HTM}^{37}\left[\mathrm{Cu}(\text { beto })_{2}\right]^{2+/ 1+}$ and $[\mathrm{Cu}-$ $\left.\left(\text { beto }_{2 \mathrm{Ox}}\right)_{2}\right]^{2+1+}$ HTMs exhibit hysteresis in reverse and forward voltage scans (Figure S4). In order to obtain the acceptably shaped IV curves, the devices employing $[\mathrm{Cu}-$

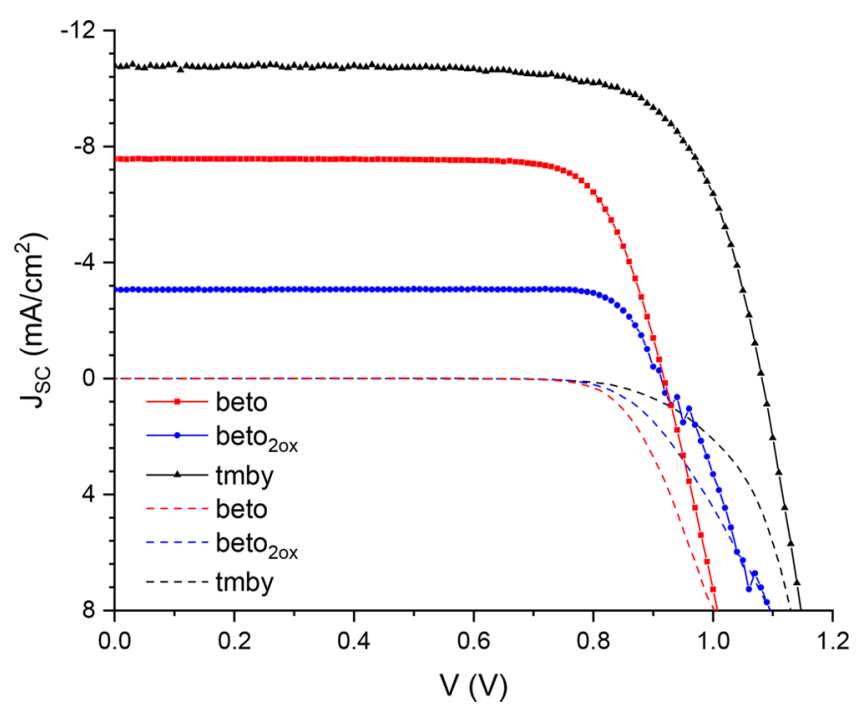

Figure 7. Current density-voltage $(J-V)$ characteristics of Y123 sensitized zombie devices employing $\left[\mathrm{Cu}(\text { beto })_{2}\right]^{2+/ 1+},[\mathrm{Cu}-$ $\left.\left(\text { beto }_{2 \mathrm{Ox}}\right)_{2}\right]^{2+/ 1+}$, and $\left[\mathrm{Cu}(\text { tmby })_{2}\right]^{2+/ 1+}$ complexes under standard AM 1.5G illumination and in the dark (the scan settling time is $0.08 \mathrm{~s}$ for $\left[\mathrm{Cu}\left(\text { beto }_{2 \mathrm{Ox}}\right)_{2}\right]^{2+/ 1+}$ and $0.04 \mathrm{~s}$ for $\left[\mathrm{Cu}(\text { beto })_{2}\right]^{2+/ 1+}$ and $[\mathrm{Cu}-$ $\left.(\text { tmby })_{2}\right]^{2+/ 1+}$, respectively).

Table 4. J-V Characteristics for the Typical Zombie Devices Employing $\left[\mathrm{Cu}(\text { beto })_{2}\right]^{2+/ 1+},\left[\mathrm{Cu}\left(\text { beto }_{2 \mathrm{O}_{x}}\right)_{2}\right]^{2+/ 1+}$, and $\left[\mathrm{Cu}(\mathrm{tmby})_{2}\right]^{2+/ 1+}$ Complexes under Standard AM 1.5G Illumination $^{a}$

\begin{tabular}{lcccc}
\multicolumn{1}{c}{ Redox couple } & $\boldsymbol{V}_{\text {oc }}(\mathbf{V})$ & $\boldsymbol{J}_{\text {sc }}\left(\mathbf{m A ~ \mathbf { ~ c m } ^ { - 2 } )}\right.$ & FF & PCE (\%) \\
{$\left[\mathrm{Cu}(\text { tmby })_{2}\right]^{2+/ 1+}$} & 1.082 & 10.79 & 0.727 & 8.48 \\
{$\left[\mathrm{Cu}(\text { beto })_{2}\right]^{2+/ 1+}$} & 0.918 & 7.57 & 0.772 & 5.43 \\
{$\left[\mathrm{Cu}\left(\text { beto }_{2 \mathrm{ox}}\right)_{2}\right]^{2+/ 1+}$} & 0.911 & 3.06 & 0.841 & 2.36
\end{tabular}

${ }^{a}$ The scan settling time is $0.08 \mathrm{~s}$ for $\left[\mathrm{Cu}\left(\text { beto }_{20 \mathrm{x}}\right)_{2}\right]^{2+/ 1+}$ and $0.04 \mathrm{~s}$ for $\left[\mathrm{Cu}(\text { beto })_{2}\right]^{2+/ 1+}$ and $\left[\mathrm{Cu}(\text { tmby })_{2}\right]^{2+/ 1+}$, respectively.

$\left.\left(\text { beto }_{2 \mathrm{Ox}}\right)_{2}\right]^{2+/ 1+}$ need slower voltage scan settling times. For $\left[\mathrm{Cu}(\text { beto })_{2}\right]^{2+/ 1+}$ and $\left[\mathrm{Cu}(\text { tmby })_{2}\right]^{2+/ 1+}$, the IV scan settling time is $0.04 \mathrm{~s}$, whereas for $\left[\mathrm{Cu}\left(\text { beto }_{2 \mathrm{Ox}}\right)_{2}\right]^{2+/ 1+}$, it is $0.08 \mathrm{~s}$. 

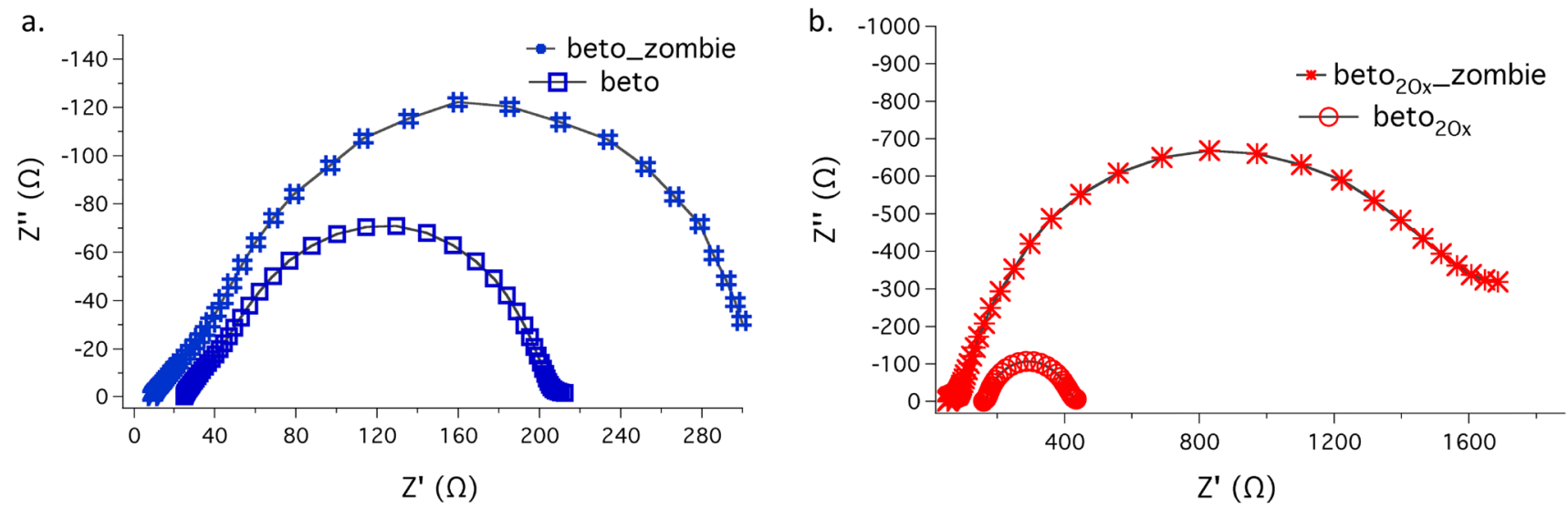

Figure 8. Nyquist plots of the dark electrochemical impedance spectra measured at an applied potential bias of $-900 \mathrm{mV}$ for liquid state and solid state devices employing (a) $\left[\mathrm{Cu}(\text { beto })_{2}\right]^{2+/ 1+}$ and (b) $\left[\mathrm{Cu}\left(\text { beto }_{2 \mathrm{Ox}}\right)_{2}\right]^{2+/ 1+}$ complexes. In order to avoid crossing of the curves, the impedance spectra offsets are applied on the bottom axis as follows: $\left[\mathrm{Cu}(\text { beto })_{2}\right]^{2+/ 1+}$ liquid state $\left(18 \Omega \mathrm{cm}^{2}\right),\left[\mathrm{Cu}\left(\text { beto }_{2 \mathrm{Ox}}\right)_{2}\right]^{2+/ 1+}$ liquid state $\left(50 \Omega \mathrm{cm}^{2}\right)$.

According to Sarker et al., 52 the hysteresis at open circuit potential originates due to the chemical capacitance at the counter electrode/electrolyte interface. This supports our experimental observation; therefore, we can state that $[\mathrm{Cu}$ $\left.\left(\text { beto }_{2 \mathrm{Ox}}\right)_{2}\right]^{2+/ 1+}$ and $\left[\mathrm{Cu}(\text { beto })_{2}\right]^{2+/ 1+}$ produce poorer electrical contact with the PEDOT counter electrode. The reasons for the poor photovoltaic performance of the solid-state devices are further investigated in terms of impedance spectroscopy and conductivity measurements as described below.

Electrochemical Impedance Spectroscopy. Electrochemical Impedance Spectroscopy (EIS) is used to investigate the effect of the copper redox mediators on liquid state devices, solid state devices, and symmetrical dummy cells. The liquid state devices, solid state devices, and dummy cells are represented by different equivalent circuits due to charge transport and cell component differences (see Figure S5). Fittings based on these equivalent circuits provide the following parameters: $R_{\text {series }}$ is the ohmic serial resistance; $R_{\mathrm{CE}}$ is the charge-transfer resistance at the counter electrode; CPce (constant phase element) is used to account for the roughness of the PEDOT counter electrode. ${ }^{53-55} R_{\mathrm{CT}}$ is the recombination resistance, and $\mathrm{CPEu}$ is the corresponding phase element.

The impedance of the constant phase element (CPce and $\mathrm{CPEu})(0 \leq \beta \leq 1)$ equals

$$
Z_{\mathrm{CPE}}=B^{-1} \cdot(i \omega)^{-\beta}
$$

where $\omega$ is the frequency, $B$ and $\beta$ are the frequencyindependent parameters of the $\mathrm{CPE}$; the corresponding parameters are 'CPE-T' $=B$ and 'CPE-P' $=\beta$. For liquid state devices, the low-frequency part of the spectrum is dominated by the Warburg impedance and it can be modeled by a finite-length element $W_{\mathrm{s}}$ with the parameters ' $W_{\mathrm{s}}-R^{\prime}$ ' $=R_{\mathrm{W}}$, ' $W_{\mathrm{s}}-T^{\prime}=T_{\mathrm{W}}$, and ' $W \mathrm{~s}-P$ ' $=0.5$. ${ }^{56,57}$ The finite length Warburg diffusion impedance is then expressed as

$$
Z_{W}=\frac{R_{W}}{\sqrt{i T_{W} \omega}} \tan \mathrm{h} \sqrt{i T_{W} \omega} ; \quad T_{W}=\frac{\delta^{2}}{D}
$$

For solid state devices, the hole transport is represented by a resistance (R1) coupled with a capacitance (CPE1) instead of the Warburg element. ${ }^{37}$
The Nyquist plots of the dark electrochemical impedance spectra and fitting parameters are provided in Figure 8 and Table S1, respectively (at $-900 \mathrm{mV}$ applied potential bias). For solid state devices, the increased $R_{\text {series }}$ values imply that the solidified electrolyte has detrimental effects across the TCO/HTM and PEDOT/HTM interfaces, especially for the $\left[\mathrm{Cu}\left(\text { beto }_{2 \mathrm{Ox}}\right)_{2}\right]^{2+/ 1+}$ zombie device (by assuming same transport resistance of the transparent conductive oxide (TCO)). For $\left[\mathrm{Cu}\left(\text { beto }_{2 \mathrm{Ox}}\right)_{2}\right]^{2+/ 1+}$, the $R_{\mathrm{CE}}$ value at the counter electrode rises due to poor PEDOT/HTM interface (Table S1). As observed in Figure 7, the liquid state devices and solid-state devices show profound differences especially in the Warburg related low frequency regions. For $\left[\mathrm{Cu}(\text { beto })_{2}\right]^{2+/ 1+}$, the Warburg resistance and hole transport resistances are obtained as 96 and $287 \Omega$ for liquid and solid-state devices, respectively. For $\left[\mathrm{Cu}\left(\text { beto }_{2 \mathrm{Ox}}\right)_{2}\right]^{2+/ 1+}$, the Warburg resistance $(70 \Omega)$ and hole transport resistances $(1541 \Omega)$ show a greater variation, indicating much poorer charge transport for the solidified $\left[\mathrm{Cu}\left(\text { beto }_{2 \mathrm{Ox}}\right)_{2}\right]^{2+/ 1+}$ electrolyte.

In order to measure diffusion coefficients for the liquid electrolytes, symmetrical dummy cells were fabricated and analyzed by EIS. The Nyquist plots of EIS measured at $0 \mathrm{~V}$ are given in Figure S6. The diffusion coefficients can be calculated as $5.33 \times 10^{-5}, 6.39 \times 10^{-5}$, and $4.37 \times 10^{-5}$ for $\left[\mathrm{Cu}\left(\text { tmby }_{2}\right]^{2+/ 1+},\left[\mathrm{Cu}(\text { beto })_{2}\right]^{2+/ 1+}\right.$, and $\left[\mathrm{Cu}\left(\text { beto }_{2 \mathrm{Ox}}\right)_{2}\right]^{2+/ 1+}$, respectively, by using eq 4 . (For the $\left[\mathrm{Cu}(\text { tmby })_{2}\right]^{2+/ 1+}$ electrolyte, the diffusion coefficient was reported as $2.6 \times$ $10^{-5} \mathrm{~cm}^{2} / \mathrm{s}$, previously, for a similar system. ${ }^{44}$ ) The diffusion coefficient values can be analyzed with regard to the DahmsRuff mechanism (eq 5), ${ }^{58,59}$ where the observed diffusion coefficient can be comprised of the mass transport by physical displacement of molecules $\left(D_{\text {mass }}\right)$ and the electron-hopping contribution

$$
D=D_{\text {mass }}+\frac{k_{e x} c \delta_{c c}^{2}}{6}
$$

where $k_{\text {ex }}$ is electron self-exchange rate constant, and $\delta_{\text {cc }}$ is the center-to center distance. As reported earlier, ${ }^{53}$ the contribution of the electron-hopping is negligible $\left(10^{-13} \mathrm{~cm}^{2} / \mathrm{s}\right)$ for similar $\mathrm{Cu}$-complex liquid electrolytes. Therefore, higher diffusion coefficient values for $\left[\mathrm{Cu}(\mathrm{tmby})_{2}\right]^{2+/ 1+}$ and $[\mathrm{Cu}-$ (beto $\left.)_{2}\right]^{2+/ 1+}$ are attributed to the smaller sizes of these complexes in comparison to the bulkier $\left[\mathrm{Cu}\left(\text { beto }_{2 \mathrm{Ox}}\right)_{2}\right]^{2+/ 1+28}$ For zombie devices, the hole transport process is presumed to 
be determined by the hopping charge transfer process ${ }^{53}$ since physical displacement of molecules is not expected and the $\delta_{\mathrm{cc}}$ values increase with the aggregation of copper complexes. For $\left.[\mathrm{Cu} \text { (beto })_{2}\right]^{2+/ 1+}$, we can assume a higher electron selfexchange rate constant in comparison to the bulkier $[\mathrm{Cu}$ $\left.\left(\text { beto }_{2 \mathrm{Ox}}\right)_{2}\right]^{2+/ 1+}$ and accordingly better hole transport (which is consistent with the lower HTM resistance value obtained from EIS). The conductivities of the HTMs were measured by interdigitated gold arrays. As observed in Figure 9, the $\left.[\mathrm{Cu} \text { (beto })_{2}\right]^{2+/ 1+}$ and $\left[\mathrm{Cu}(\text { tmby })_{2}\right]^{2+/ 1+}$ showed better conductivities in comparison to that of $\left[\mathrm{Cu}\left(\text { beto }_{2 \mathrm{Ox}}\right)_{2}\right]^{2+/ 1+}$.

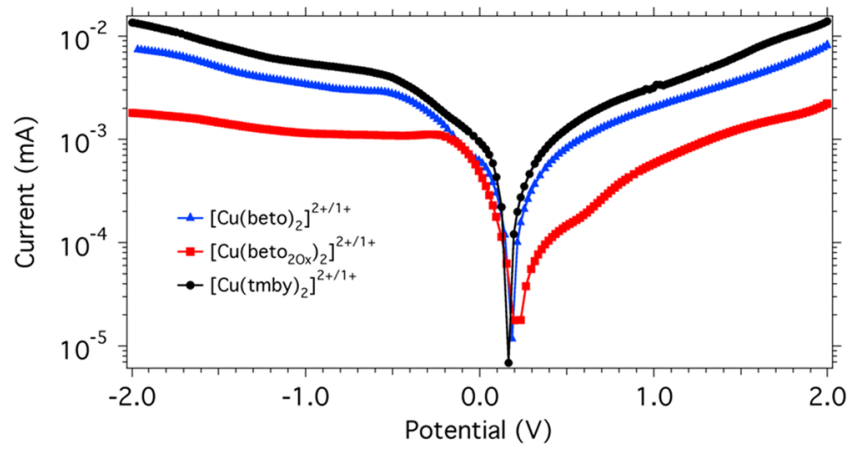

Figure 9. Current Voltage characteristics of HTM films on interdigitated Au electrodes (the HTMs deposited by drop-casting).

The poor charge transport with $\left[\mathrm{Cu}(\text { beto })_{2}\right]^{2+/ 1+}$ and $\left[\mathrm{Cu}\left(\text { beto }_{2 \mathrm{Ox}}\right)_{2}\right]^{2+/ 1+}$ can explain the obtained lower photovoltaic performance of these solid state devices. A poor electrical contact between the zombie HTM and PEDOT is another possibility. Interestingly, the diminished charge transport properties with $\left.[\mathrm{Cu} \text { (beto })_{2}\right]^{2+/ 1}$ and $[\mathrm{Cu}$ $\left.\left(\text { beto }_{2 \mathrm{Ox}}\right)_{2}\right]^{2+/ 1+}$ only affects the $J_{\mathrm{SC}}$ values (Table 3 ). With low $J_{S C}$ values, the obtained fill factor values are still high. The origin of this unusual result will be investigated in future studies.

\section{CONCLUSION}

We reported the synthesis, characterizations, and photovoltaic performances of two new copper redox mediators for dyesensitized solar cells. The copper coordination complexes were obtained from 6,6'-dimethyl-2,2' -bipyridine ligands that were functionalized at the $4,4^{\prime}$ positions by ethoxy or methoxyethoxy chains. The resulting organometallic $\mathrm{Cu}(\mathrm{I})$ coordination complexes of these ligands showed reversible formal potentials of approximately $0.8 \mathrm{~V}$ vs SHE, which is negatively shifted by approximately $70 \mathrm{mV}$ vs SHE compared to the standard $\left[\mathrm{Cu}(\mathrm{tmby})_{2}\right]^{2+/+}$ redox couple. Single crystal X-ray diffraction measurements performed on $\left[\mathrm{Cu}(\text { beto })_{2}\right][\mathrm{TFSI}]$ showed strong geometric similarities in the coordination sphere with $\left[\mathrm{Cu}(\mathrm{tmby})_{2}\right]^{+}$, indicating that these new ligands did not affect the structural environment of the copper metal center. X-ray diffraction measurements showed that $[\mathrm{Cu}-$ $\left.\left(\text { beto }_{2 \mathrm{Ox}}\right)_{2}\right]^{2+/ 1+}$ films had a reduced crystallinity compared to those of the films made of $\left[\mathrm{Cu}(\text { beto })_{2}\right]^{2+/ 1+}$ and $[\mathrm{Cu}-$ $\left.(\text { tmby })_{2}\right]^{2+/ 1}$. Transient absorption spectroscopy showed that $\left.[\mathrm{Cu} \text { (beto })_{2}\right]^{2+/ 1}$ and $\left[\mathrm{Cu}\left(\text { beto }_{2 \mathrm{Ox}}\right)_{2}\right]^{2+/ 1+}$ benefit from the higher driving force for dye regeneration, which allows them to have high dye regeneration efficiencies despite their bulkier structures. The performances of liquid DSCs fabricated with the new coordination complexes were found to be $10.4 \%$ and
$10.2 \%$ for $\left[\mathrm{Cu}(\text { beto })_{2}\right]^{2+/ 1}$ and $\left[\mathrm{Cu}\left(\text { beto }_{2 \mathrm{Ox}}\right)_{2}\right]^{2+/ 1+}$ electrolytes, respectively, under AM $1.5 \mathrm{G}$ illumination. However, the zombie devices performed poorly in addition to presenting strong hysteresis. These findings were explained by the increased charge transfer resistances induced by the $[\mathrm{Cu}-$ (beto $\left.)_{2}\right]^{2+/ 1}$ and $\left[\mathrm{Cu}\left(\text { beto }_{2 \mathrm{Ox}}\right)_{2}\right]^{2+/ 1+}$ complexes as evidenced by electrochemical impedance spectroscopy and poorer PEDOT/HTM contact. We showed that structural modifications of the ligands based on a 6,6'-dimethyl-2,2'-bipyridine scaffold do not alter the photovoltaic performances of the liquid devices but change the morphology and charge transfer properties of the films in the zombie cells and photovoltaic performance accordingly.

\section{ASSOCIATED CONTENT}

\section{Supporting Information}

The Supporting Information is available free of charge at https://pubs.acs.org/doi/10.1021/acs.jpcc.0c00671.

Synthesis and characterization of the ligands and copper complexes, UV-vis spectra, XRD data, hysteresis and EIS data (PDF)

\section{AUTHOR INFORMATION}

\section{Corresponding Author}

Anders Hagfeldt - Laboratory of Photomolecular Science, Institute of Chemical Sciences and Engineering, Ecole Polytechnique Féderale de Lausanne, 1015 Lausanne, Switzerland; orcid.org/0000-0001-6725-8856; Email: anders.hagfeldt@epfl.ch

\section{Authors}

Yasemin Saygili - Laboratory of Photomolecular Science, Institute of Chemical Sciences and Engineering, Ecole Polytechnique Féderale de Lausanne, 1015 Lausanne, Switzerland

Marko Stojanovic - Laboratory for Photonics and Interfaces, Institute of Chemical Sciences, Engineering, Ecole Polytechnique Féderale de Lausanne, 1015 Lausanne, Switzerland

Hui-Seon Kim - Laboratory of Photomolecular Science, Institute of Chemical Sciences and Engineering, Ecole Polytechnique Federale de Lausanne, 1015 Lausanne, Switzerland; (1) orcid.org/0000-0002-9928-3033

Joel Teuscher - Photochemical Dynamics Group, Ecole Polytechnique Féderale de Lausanne, 1015 Lausanne, Switzerland

Rosario Scopelliti - Institut des Sciences et Ingenierie Chimiques, Ecole Polytechnique Féderale de Lausanne, 1015 Lausanne, Switzerland; ㅇorcid.org/0000-0001-8161-8715

Marina Freitag - Department of Chemistry- Angström Laboratory, Uppsala University, 75120 Uppsala, Sweden; (1) orcid.org/0000-0002-4954-6851

Shaik M. Zakeeruddin - Laboratory of Photomolecular Science, Institute of Chemical Sciences and Engineering, Ecole Polytechnique Féderale de Lausanne, 1015 Lausanne, Switzerland

Jacques-E. Moser - Photochemical Dynamics Group, Ecole Polytechnique Féderale de Lausanne, 1015 Lausanne, Switzerland; orcid.org/0000-0003-0747-4666

Michael Grätzel - Laboratory for Photonics, and Interfaces, Institute of Chemical Sciences, Engineering, Ecole Polytechnique Féderale de Lausanne, 1015 Lausanne, Switzerland; ○ orcid.org/0000-0002-0068-0195 
Complete contact information is available at:

https://pubs.acs.org/10.1021/acs.jpcc.0c00671

\section{Author Contributions}

$\$$ These authors contributed equally.

\section{Notes}

The authors declare no competing financial interest.

\section{ACKNOWLEDGMENTS}

We acknowledge the Swiss National Science Foundation with the project entitled as "Fundamental studies of dye-sensitized and perovskite solar cells" with project number 200020_169695 and Exeger Operations AB, Sweden for financial support. H.-S.K is thankful for the financial support from the GRAPHENE Flagship Core 2 project supported by the European Commission H2020 Programme under contract 785219.

\section{REFERENCES}

(1) Yun, S.; Qin, Y.; Uhl, A. R.; Vlachopoulos, N.; Yin, M.; Li, D. D.; Han, X.; Hagfeldt, A. New-Generation Integrated Devices Based on Dye-Sensitized and Perovskite Solar Cells. Energy Environ. Sci. 2018, 476, 476-526.

(2) Grätzel, M. Dye-Sensitized Solar Cells. J. Photochem. Photobiol., C 2003, 4, 145-153.

(3) Mozaffari, S.; Nateghi, M. R.; Zarandi, M. B. An Overview of the Challenges in the Commercialization of Dye Sensitized Solar Cells. Renewable Sustainable Energy Rev. 2017, 71, 675-686.

(4) Sharma, S.; Bulkesh, Siwach; Ghoshal, S. K.; Mohan, D. Dye Sensitized Solar Cells: From Genesis to Recent Drifts. Renewable Sustainable Energy Rev. 2017, 70, 529-537.

(5) Allardyce, C. S.; Fankhauser, C.; Zakeeruddin, S. M.; Grätzel, M.; Dyson, P. J. The Influence of Greenhouse-Integrated Photovoltaics on Crop Production. Sol. Energy 2017, 155, 517-522.

(6) Sun, J.; Jasieniak, J. J. Semi-Transparent Solar Cells. J. Phys. D: Appl. Phys. 2017, 50, 9.

(7) Cao, Y.; Liu, Y.; Zakeeruddin, S. M.; Hagfeldt, A.; Grätzel, M. Direct Contact of Selective Charge Extraction Layers Enables HighEfficiency Molecular Photovoltaics. Joule 2018, 2, 1108-1117.

(8) Freitag, M.; Teuscher, J.; Saygili, Y.; Zhang, X.; Giordano, F.; Liska, P.; Hua, J.; Zakeeruddin, S. M.; Moser, J.-E.; Grätzel, M.; et al. Dye-Sensitized Solar Cells for Efficient Power Generation under Ambient Lighting. Nat. Photonics 2017, 11, 372-378.

(9) O’Regan, B.; Gratzel, M. A Low-Cost, High-Efficiency Solar Cell Based on Dye-Sensitized Colloidal TiO2 Films. Nature 1991, 353, 737-740.

(10) Yao, Z.; Zhang, M.; Li, R.; Yang, L.; Qiao, Y.; Wang, P. A Metal-Free n-Annulated Thienocyclopentaperylene Dye: Power Conversion Efficiency of $12 \%$ for Dye-Sensitized Solar Cells. Angew. Chem., Int. Ed. 2015, 54, 5994-5998.

(11) Hagberg, D. P.; Jiang, X.; Gabrielsson, E.; Linder, M.; Marinado, T.; Brinck, T.; Hagfeldt, A.; Sun, L. Symmetric and Unsymmetric Donor Functionalization. Comparing Structural and Spectral Benefits of Chromophores for Dye-Sensitized Solar Cells. J. Mater. Chem. 2009, 19, 7232-7238.

(12) Yum, J.; Holcombe, T. W.; Kim, Y.; Rakstys, K.; Moehl, T.; Teuscher, J.; Delcamp, J. H.; Nazeeruddin, M. K.; Grätzel, M. BlueColoured Highly Efficient Dye-Sensitized Solar Cells by Implementing the Diketopyrrolopyrrole Chromophore. Sci. Rep. 2013, 3, 2446.

(13) Ren, Y.; Sun, D.; Cao, Y.; Tsao, H. N.; Yuan, Y.; Zakeeruddin, S. M.; Wang, P.; Grätzel, M. A Stable Blue Photosensitizer for Color Palette of Dye-Sensitized Solar Cells Reaching 12.6\% Efficiency. J. Am. Chem. Soc. 2018, 140, 2405-2408.

(14) Wu, Y.; Zhu, W. Organic Sensitizers from D- $\mathrm{D}-\mathrm{A}$ to $\mathrm{D}-$ $\mathrm{A}-\pi-\mathrm{A}$ : Effect of the Internal Electron-Withdrawing Units on Molecular Absorption, Energy Levels and Photovoltaic Performances. Chem. Soc. Rev. 2013, 42, 2039-2058.
(15) Bella, F.; Galliano, S.; Gerbaldi, C.; Viscardi, G. Cobalt-Based Electrolytes for Dye-Sensitized Solar Cells: Recent Advances towards Stable Devices. Energies 2016, 9, 384.

(16) Magni, M.; Biagini, P.; Colombo, A.; Dragonetti, C.; Roberto, D.; Valore, A. Versatile Copper Complexes as a Convenient Springboard for Both Dyes and Redox Mediators in Dye Sensitized Solar Cells. Coord. Chem. Rev. 2016, 322, 69-93.

(17) Hagfeldt, A.; Boschloo, G.; Sun, L.; Kloo, L.; Pettersson, H. Dye-Sensitized Solar Cells. Chem. Rev. 2010, 110, 6595-6663.

(18) Saygili, Y.; Stojanovic, M.; Flores-Díaz, N.; Zakeeruddin, S. M.; Vlachopoulos, N.; Grätzel, M.; Hagfeldt, A. Metal Coordination Complexes as Redox Mediators in Regenerative Dye-Sensitized Solar Cells. Inorganics 2019, 7, 30.

(19) Benesperi, I.; Michaels, H.; Freitag, M. The Researcher's Guide to Solid-State Dye-Sensitized Solar Cells. J. Mater. Chem. C 2018, 6, 11903-11942.

(20) Rorabacher, D. B. Electron Transfer by Copper Centers. Chem. Rev. 2004, 104, 651-698.

(21) Feldt, S. M.; Wang, G.; Boschloo, G.; Hagfeldt, A. Effects of Driving Forces for Recombination and Regeneration on the Photovoltaic Performance of Dye-Sensitized Solar Cells Using Cobalt Polypyridine Redox Couples. J. Phys. Chem. C 2011, 115, 2150021507.

(22) Yella, a.; Lee, H.-W.; Tsao, H. N.; Yi, C.; Chandiran, a. K.; Nazeeruddin, M. K.; Diau, E. W.-G.; Yeh, C.-Y.; Zakeeruddin, S. M.; Gratzel, M. Porphyrin-Sensitized Solar Cells with Cobalt (II/III)Based Redox Electrolyte Exceed 12\% Efficiency. Science 2011, 334, 629-634.

(23) Mathew, S.; Yella, A.; Gao, P.; Humphry-Baker, R.; Curchod, B. F. E.; Ashari-Astani, N.; Tavernelli, I.; Rothlisberger, U.; Nazeeruddin, M.. K.; Gratzel, M. Dye-sensitized solar cells with $13 \%$ efficiency achieved through the molecular engineering of porphyrin sensitizers. Nat. Chem. 2014, 6, 242-247.

(24) Feldt, S. M.; Lohse, P. W.; Kessler, F.; Nazeeruddin, M. K.; Gratzel, M.; Boschloo, G.; Hagfeldt, A. Regeneration and Recombination Kinetics in Cobalt Polypyridine Based Dye-Sensitized Solar Cells, Explained Using Marcus Theory. Phys. Chem. Chem. Phys. 2013, 15, 7087-7097.

(25) Saygili, Y.; Söderberg, M.; Pellet, N.; Giordano, F.; Cao, Y.; Muñoz-García, A. B.; Zakeeruddin, S. M. S. M.; Vlachopoulos, N.; Pavone, M.; Boschloo, G.; et al. Copper Bipyridyl Redox Mediators for Dye-Sensitized Solar Cells with High Photovoltage. J. Am. Chem. Soc. 2016, 138, 15087-15096.

(26) Liu, Z.; Duan, K.; Guo, H.; Deng, Y.; Huang, H.; Yi, X.; Chen, H.; Tan, S. The Enhancement of Photovoltaic Properties of the DSSCs Based on $\mathrm{D}-\mathrm{A}-\pi-\mathrm{A}$ Organic Dyes via Tuning Auxiliary Acceptor. Dyes Pigm. 2017, 140, 312-319.

(27) Feldt, S. M.; Gibson, E. A.; Gabrielsson, E.; Sun, L.; Boschloo, G.; Hagfeldt, A. Design of Organic Dyes and Cobalt Polypyridine Redox Mediators for High-Efficiency Dye-Sensitized Solar Cells. J. Am. Chem. Soc. 2010, 132, 16714-16724.

(28) Freitag, M.; Giordano, F.; Yang, W.; Pazoki, M.; Hao, Y.; Zietz, B.; Gra, M.; Hagfeldt, A.; Boschloo, G. Copper Phenanthroline as a Fast and High-Performance Redox Mediator for Dye-Sensitized Solar Cells. J. Phys. Chem. C 2016, 120, 9595-9603.

(29) Liang, M.; Chen, J. Arylamine Organic Dyes for Dye-Sensitized Solar Cells. Chem. Soc. Rev. 2013, 42, 3453-3488.

(30) O’Regan, B.; Lenzmann, F.; Muis, R.; Wienke, J. A Solid-State Dye-Sensitized Solar Cell Fabricated with Pressure-Treated P25$\mathrm{TiO} 2$ and CuSCN: Analysis of Pore Filling and IV Characteristics. Chem. Mater. 2002, 14, 5023-5029.

(31) Tennakone, K.; Kumara, G. R. R. A.; Kottegoda, I. R. M.; Wijayantha, K. G. U.; Perera, V. P. S. A Solid-State Photovoltaic Cell Sensitized with a Ruthenium Bipyridyl Complex. J. Phys. D: Appl. Phys. 1998, 31, 1492.

(32) Zhang, J.; Vlachopoulos, N.; Jouini, M.; Johansson, M. B.; Zhang, X.; Nazeeruddin, M. K.; Boschloo, G.; Johansson, E. M. J.; Hagfeldt, A. Efficient Solid-State Dye Sensitized Solar Cells: The Influence of Dye Molecular Structures for the in-Situ Photo- 
electrochemically Polymerized PEDOT as Hole Transporting Material. Nano Energy 2016, 19, 455-470.

(33) Xu, B.; Gabrielsson, E.; Safdari, M.; Cheng, M.; Hua, Y.; Tian, H.; Gardner, J. M.; Kloo, L.; Sun, L. 1,1,2,2-Tetrachloroethane (TeCA) as a Solvent Additive for Organic Hole Transport Materials and Its Application in Highly Efficient Solid-State Dye-Sensitized Solar Cells. Adv. Energy Mater. 2015, 5, 1402340.

(34) Lee, B.; Stoumpos, C. C.; Zhou, N.; Hao, F.; Malliakas, C.; Yeh, C.-Y.; Marks, T. J.; Kanatzidis, M. G.; Chang, R. P. H. Air-Stable Molecular Semiconducting Iodosalts for Solar Cell Applications: Cs2SnI6 as a Hole Conductor. J. Am. Chem. Soc. 2014, 136, 1537915385 .

(35) Freitag, M.; Daniel, Q.; Pazoki, M.; Sveinbjornsson, K.; Zhang, J.; Sun, L.; Hagfeldt, A.; Boschloo, G.; Sveinbjörnsson, K.; Zhang, J.; et al. High-Efficiency Dye-Sensitized Solar Cells with Molecular Copper Phenanthroline as Solid Hole Conductor. Energy Environ. Sci. 2015, 8, 2634-2637.

(36) Kashif, M. K.; Milhuisen, R. A.; Nippe, M.; Hellerstedt, J.; Zee, D. Z.; Duffy, N. W.; Halstead, B.; De Angelis, F.; Fantacci, S.; Fuhrer, M. S. Cobalt Polypyridyl Complexes as Transparent SolutionProcessable Solid-State Charge Transport Materials. Adv. Energy Mater. 2016, 6, 1600874.

(37) Cao, Y.; Saygili, Y.; Ummadisingu, A.; Teuscher, J.; Luo, J.; Pellet, N.; Giordano, F.; Zakeeruddin, S. M. S. M.; Moser, J.-E. J.-E.; Freitag, M.; et al. 11\% Efficiency Solid-State Dye-Sensitized Solar Cells with Copper(II/I) Hole Transport Materials. Nat. Commun. 2017, 8, 15390.

(38) Zhang, W.; Wu, Y.; Bahng, H. W.; Cao, Y.; Yi, C.; Saygili, Y.; Luo, J.; Liu, Y.; Kavan, L.; Moser, J. E.; et al. Comprehensive Control of Voltage Loss Enables 11.7\% Efficient Solid-State Dye-Sensitized Solar Cells. Energy Environ. Sci. 2018, 11, 1779-1787.

(39) Ding, I.-K.; Tétreault, N.; Brillet, J.; Hardin, B. E.; Smith, E. H.; Rosenthal, S. J.; Sauvage, F.; Grätzel, M.; McGehee, M. D. PoreFilling of Spiro-OMeTAD in Solid-State Dye Sensitized Solar Cells: Quantification, Mechanism, and Consequences for Device Performance. Adv. Funct. Mater. 2009, 19, 2431-2436.

(40) Malinauskas, T.; Tomkute-Luksiene, D.; Sens, R.; Daskeviciene, M.; Send, R.; Wonneberger, H.; Jankauskas, V.; Bruder, I.; Getautis, V. Enhancing Thermal Stability and Lifetime of Solid-State DyeSensitized Solar Cells via Molecular Engineering of the HoleTransporting Material Spiro-OMeTAD. ACS Appl. Mater. Interfaces 2015, 7, 11107-11116.

(41) Kovalevsky, A. Y.; Gembicky, M.; Novozhilova, I. V.; Coppens, P. Solid-State Structure Dependence of the Molecular Distortion and Spectroscopic Properties of the $\mathrm{Cu}(\mathrm{I})$ Bis(2,9-Dimethyl-1,10Phenanthroline) Ion. Inorg. Chem. 2003, 42, 8794-8802.

(42) Housecroft, C. E.; Constable, E. C. The Emergence of Copper(I)-Based Dye Sensitized Solar Cells. Chem. Soc. Rev. 2015, 44, $8386-8398$.

(43) Haanstra, W. G.; Driessen, W. L.; Reedijk, J.; Cabral, M. F.; de Cabral, J. O. Unusually High Redox Potentials of Two Copper(II) Compounds of 1, 8-Bis(3, 5-Dimethyl-1-Pyrazolyl)-3, 6-Dithiaoctane. Inorg. Chem. 1992, 31, 3150-3151.

(44) Ferdowsi, P.; Saygili, Y.; Zakeeruddin, S. M.; Mokhtari, J.; Grätzel, M.; Hagfeldt, A.; Kavan, L. Alternative Bases to 4-TertButylpyridine for Dye-Sensitized Solar Cells Employing Copper Redox Mediator. Electrochim. Acta 2018, 265, 194-201.

(45) Pavlishchuk, V. V.; Addison, A. W. Conversion Constants for Redox Potentials Measured versus Different Reference Electrodes in Acetonitrile Solutions at $25^{\circ} \mathrm{C}$. Inorg. Chim. Acta 2000, 298, 97-102.

(46) Ellis, H.; Vlachopoulos, N.; Haggman, L.; Perruchot, C.; Jouini, M.; Boschloo, G.; Hagfeldt, A. PEDOT Counter Electrodes for DyeSensitized Solar Cells Prepared by Aqueous Micellar Electrodeposition. Electrochim. Acta 2013, 107, 45-51.

(47) Fabregat-Santiago, F.; Bisquert, J.; Garcia-Belmonte, G.; Boschloo, G.; Hagfeldt, A. Influence of Electrolyte in Transport and Recombination in Dye-Sensitized Solar Cells Studied by Impedance Spectroscopy. Sol. Energy Mater. Sol. Cells 2005, 87, 117-131.
(48) Zhang, X.; Xu, Y.; Giordano, F.; Schreier, M.; Pellet, N.; Hu, Y.; Yi, C.; Robertson, N.; Hua, J.; Zakeeruddin, S. M.; et al. Molecular Engineering of Potent Sensitizers for Very Efficient Light Harvesting in Thin-Film Solid-State Dye-Sensitized Solar Cells. J. Am. Chem. Soc. 2016, 138, 10742-10745.

(49) Burke, P. J.; Henrick, K.; McMillin, D. R. Crystal and Molecular Structures of Bis $\left(4,4^{\prime}, 6,6^{\prime}\right.$-Tetramethyl-2,2'-Bipyridyl)Copper(I) Perchlorate, Bis $\left(4,4^{\prime}, 6,6^{\prime}\right.$-Tetramethyl-2,2' -Bipyridyl)Copper(II) Diperchlorate, and $\operatorname{Bis}\left(4,4^{\prime}, 6,6^{\prime}\right.$-Tetramethyl-2,2'-Bipyridyl)Copper(II) Diperchlorate Dihydrate. A Searc. Inorg. Chem. 1982, 21, 1881-1886.

(50) Burke, P. J.; McMillin, D. R.; Robinson, W. R. Crystal and Molecular Structure of $\operatorname{Bis}\left(6,6^{\prime}\right.$-Dimethyl-2,2'-Bipyridyl)Copper(I) Tetrafluoroborate. Inorg. Chem. 1980, 19, 1211-1214.

(51) Saygili, Y.; Stojanovic, M.; Michaels, H.; Tiepelt, J.; Teuscher, J.; Massaro, A.; Pavone, M.; Giordano, F.; Zakeeruddin, S. M.; Boschloo, G.; et al. The Effect of Coordination Sphere Geometry of Copper Redox Mediators on Regeneration and Recombination Behavior in Dye-Sensitized Solar Cell Applications. ACS Appl. Energy Mater. 2018, 1, 4950-4962.

(52) Sarker, S.; Seo, H. W.; Jin, Y.-K.; Lee, K.-S.; Lee, M.; Kim, D. M. On the Hysteresis of Current Density-Voltage Curves of DyeSensitized Solar Cells. Electrochim. Acta 2015, 182, 493-499.

(53) Kavan, L.; Saygili, Y.; Freitag, M.; Zakeeruddin, S. M. S. M.; Hagfeldt, A.; Grätzel, M. Electrochemical Properties of $\mathrm{Cu}(\mathrm{II} / \mathrm{I})$ Based Redox Mediators for Dye-Sensitized Solar Cells. Electrochim. Acta 2017, 227, 194-202.

(54) Kavan, L.; Krysova, H.; Janda, P.; Tarabkova, H.; Saygili, Y.; Freitag, M.; Zakeeruddin, S. M.; Hagfeldt, A.; Grätzel, M. Novel Highly Active Pt/Graphene Catalyst for Cathodes of $\mathrm{Cu}(\mathrm{II} / \mathrm{I})$ Mediated Dye-Sensitized Solar Cells. Electrochim. Acta 2017, 251, $167-175$.

(55) Kavan, L.; Yum, J.-H.; Grätzel, M. Graphene Nanoplatelets Outperforming Platinum as the Electrocatalyst in Co-BipyridineMediated Dye-Sensitized Solar Cells. Nano Lett. 2011, 11, 55015506.

(56) Kim, J.-Y.; Kim, J. Y.; Lee, D.-K.; Kim, B.; Kim, H.; Ko, M. J. Importance of 4-Tert-Butylpyridine in Electrolyte for Dye-Sensitized Solar Cells Employing SnO2 Electrode. J. Phys. Chem. C 2012, 116, 22759-22766.

(57) Kang, S. H.; Kim, J.-Y.; Kim, H. S.; Koh, H.-D.; Lee, J.-S.; Sung, Y.-E. Influence of Light Scattering Particles in the TiO2 Photoelectrode for Solid-State Dye-Sensitized Solar Cell. J. Photochem. Photobiol., A 2008, 200, 294-300.

(58) Blauch, D. N.; Saveant, J. M. Dynamics of Electron Hopping in Assemblies of Redox Centers. Percolation and Diffusion. J. Am. Chem. Soc. 1992, 114, 3323-3332.

(59) Barrosse-Antle, L. E.; Bond, A. M.; Compton, R. G.; O'Mahony, A. M.; Rogers, E. I.; Silvester, D. S. Voltammetry in Room Temperature Ionic Liquids: Comparisons and Contrasts with Conventional Electrochemical Solvents. Chem. - Asian J. 2010, 5, 202-230. 



\section{SUPPORTING INFORMATION}

\section{Liquid State and Zombie Dye Sensitized Solar Cells with Copper Bipyridine Complexes Functionalized with Alkoxy Groups}

Yasemin Saygilii ${ }^{1+}$, Marko Stojanovic ${ }^{2+}$, Hui-Seon Kim ${ }^{1}$, Joel Teuscher ${ }^{3}$, Rosario Scopelliti ${ }^{5}$, Marina Freitag ${ }^{4}$, Shaik M. Zakeeruddin ${ }^{1}$, Jacques-E. Moser ${ }^{3}$, Michael Grätzel ${ }^{2}$, Anders Hagfeldt ${ }^{1 *}$

${ }^{1}$ Laboratory of Photomolecular Science, Institute of Chemical Sciences and Engineering, École Polytechnique Fédérale de Lausanne, 1015, Lausanne, Switzerland.

${ }^{2}$ Laboratory for Photonics and Interfaces, Institute of Chemical Sciences, Engineering École Polytechnique Fédérale de Lausanne, 1015 Lausanne, Switzerland

${ }^{3}$ Photochemical Dynamics Group, Ecole Polytechnique Fédérale de Lausanne, 1015 Lausanne, Switzerland

${ }^{4}$ Department of Chemistry- Ångström Laboratory, Uppsala University, 75120 Uppsala, Sweden

${ }^{5}$ Institut des Sciences et Ingenierie Chimiques, Ecole Polytechnique Fédérale de Lausanne, 1015 Lausanne, Switzerland 


\section{Synthesis of the Ligands}

General information: Commercially available chemicals were used without any additional purification step. N,N-dimehtylformamide(DMF) was purchased over Molecular Sieve from ACROS Organics ${ }^{\mathrm{TM}}$, Sodium Hydride $(\mathrm{NaH})$ was purchased as a moistened oil (55-65\% wt) from Sigma Aldrich ${ }^{\mathrm{TM}} .{ }^{1} \mathrm{H}$ and ${ }^{13} \mathrm{C}$ NMR spectra were recorded on Bruker AvanceIII-400 MHz NMR spectrometer. Chemical shifts are reported in parts per million (ppm, $\delta$ ) and referenced to tetramethylsilane $(0 \mathrm{ppm})$ or solvent residual peak $(7.26 \mathrm{ppm}$ for $1 \mathrm{H}$ NMR and $77.0 \mathrm{ppm}$ for $13 \mathrm{C}$ NMR) as internal standard. Mass spectra were collected on a HITACHI-80 mass spectrometer.
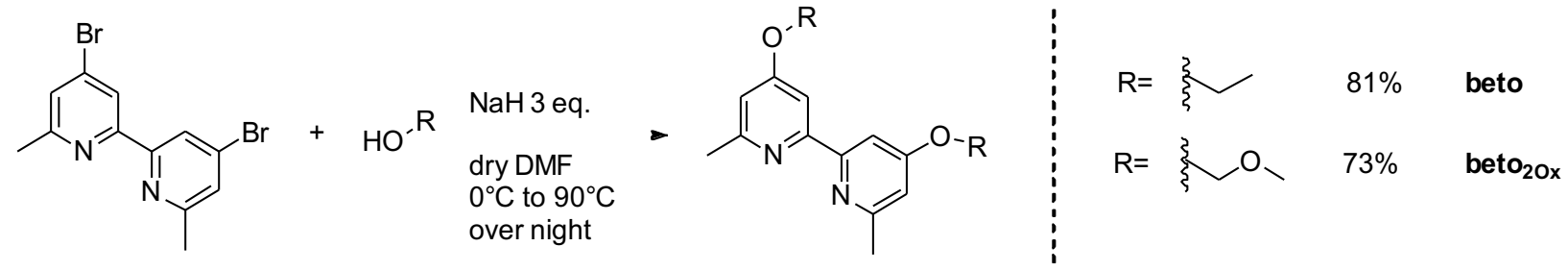

Scheme S1: Synthesis of beto and beto $20 x$ ligands.

4,4'-bis(2-methoxyethoxy)-6,6'-dimethyl-2,2'-bipyridine(beto2ox)

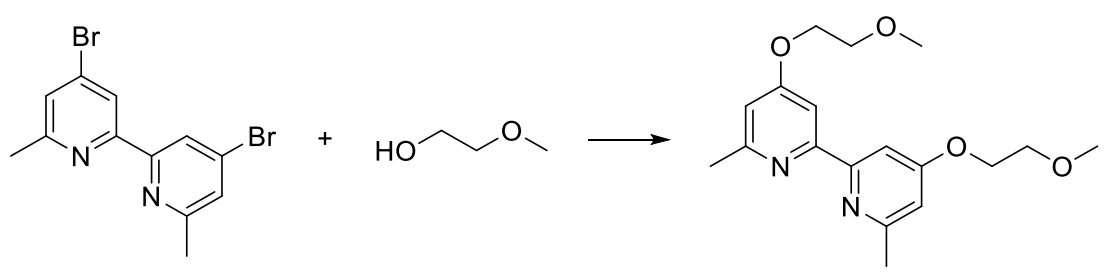

Sodium hydride $(0.150 \mathrm{~g}, 6.14 \mathrm{mmol}, 3$ eq. $)$ was added to $20 \mathrm{~mL}$ of anhydrous $\mathrm{DMF}$ at $0^{\circ} \mathrm{C}$. The resulting suspension was stirred for 10 minutes after which 2-methoxyethan-1-ol $(0.620$ g, 8.19 mmol, 4 eq.) was added dropwise to afford the formation of hydrogen gas. The solution was then left at $0^{\circ} \mathrm{C}$ for 2 hours. 4,4'-dibromo-6,6'-dimethyl-2,2'-bipyridine $(0.7 \mathrm{~g}$, $2.05 \mathrm{mmol}, 1$ eq.) was added to the opaque mixture and the ice bath was removed to allow the reaction mixture to slowly warm up to room temperature. The beige opaque suspension was then heat at $90^{\circ} \mathrm{C}$ overnight. The dark green solution was then cooled down to RT, quenched with a saturated solution of ammonium chloride $(200 \mathrm{~mL})$. And the organics were extracted with DCM $(3 \times 100 \mathrm{~mL})$. DCM was then removed and the residue dissolved in diethyl ether $(100 \mathrm{~mL})$. The organic phase was washed with deionized water $(3 \times 100 \mathrm{~mL})$ and a saturated solution of sodium chloride $(100 \mathrm{~mL})$. The obtained yellow solution was dried over magnesium sulfate followed by evaporation of the diethyl ether. The product was obtained as a yellow solid $0.5 \mathrm{~g}$ (73\% yield). 
H NMR (400 MHz, Chloroform-d) $\delta 7.81(\mathrm{~d}, \mathrm{~J}=2.3 \mathrm{~Hz}, 2 \mathrm{H}), 6.75(\mathrm{~d}, \mathrm{~J}=2.3 \mathrm{~Hz}, 2 \mathrm{H}), 4.30(\mathrm{t}, \mathrm{J}=4.7 \mathrm{~Hz}$, $5 \mathrm{H}), 3.81(\mathrm{t}, \mathrm{J}=4.7 \mathrm{~Hz}, 5 \mathrm{H}), 3.49(\mathrm{~s}, 6 \mathrm{H}), 2.58(\mathrm{~s}, 6 \mathrm{H})$; :C NMR (101 MHz, Chloroform- $d$ ) $\delta 166.03,159.23$, 157.56, 110.22, 104.32, 70.71, 67.07, 59.26, 24.71; MS (APPI,$m / z)$ : [M+H+] calculated: 333.1809 found:

333.1809

4,4'-diethoxy-6,6'-dimethyl-2,2'-bipyridine(beto)<smiles>CCOc1cc(C)nc(-c2cc(OCC)cc(C)n2)c1</smiles>

Sodium hydride $(0.250 \mathrm{~g}, 10.53 \mathrm{mmol}, 3$ eq. $)$ was added to $20 \mathrm{~mL}$ of anhydrous DMF at $0^{\circ} \mathrm{C}$. The resulting suspension was stirred for 10 minutes after which $5 \mathrm{~mL}$ of Ethanol was added dropwise under vigorous stirring to afford the formation of hydrogen gas. The solution was then left at $0^{\circ} \mathrm{C}$ for 2 hours. 4,4'-dibromo-6,6'-dimethyl-2,2'-bipyridine $(1.2 \mathrm{~g}, 3.51 \mathrm{mmol}, 1$ eq.) was added to the opaque mixture and the ice bath was removed to allow the reaction mixture to slowly warm up to room temperature. The beige opaque suspension was then heat at $65^{\circ} \mathrm{C}$ overnight. The dark green solution was then cooled down to RT, quenched with a saturated solution of ammonium chloride until neutral $\mathrm{pH}$ and diluted with deionized water. The organics were collected by extraction with Ether followed by drying over magnesium sulfate. The product was obtained as a beige crystalline solid: $0.671 \mathrm{~g} \mathrm{(70 \%} \mathrm{yield).}$

${ }^{1} \mathrm{H}$ NMR (400 MHz, Chloroform-d) $\delta 7.76(\mathrm{~d}, J=2.3 \mathrm{~Hz}, 2 \mathrm{H}), 6.69$ (d, $\left.J=2.4 \mathrm{~Hz}, 2 \mathrm{H}\right), 4.21$ (q, $J=7.0 \mathrm{~Hz}, 4 \mathrm{H}), 2.58(\mathrm{~s}, 6 \mathrm{H}), 1.47(\mathrm{t}, J=7.0 \mathrm{~Hz}, 6 \mathrm{H}) ;{ }^{13} \mathrm{C} \mathrm{NMR}(101 \mathrm{MHz}$, Chloroformd) $\delta 166.20,159.16,157.64,109.89,104.52,63.44,24.73,14.63 ; \mathrm{MS}\left(\mathrm{APPI}^{+}, m / z\right):\left[\mathrm{M}+\mathrm{H}^{+}\right]$ calculated: 273.1598 found: 273.1600

\section{Synthesis of the $\mathrm{Cu}(\mathrm{I})$ complexes}

For $\left[\mathrm{Cu}(\text { beto })_{2}\right][\mathrm{TFSI}]$ and $\left[\mathrm{Cu}\left(\text { beto }_{20 \mathrm{x}}\right)_{2}\right][\mathrm{TFSI}]$, one equivalent of $\mathrm{CuI}(35 \mathrm{mg}, 0.175 \mathrm{mmol})$ was mixed with 3 equivalents of 4,4'-diethoxy-6.6'-dimethyl-2,2'-bipyridine (190mg, 0.7 mmol) or 4,4'-bis(2-methoxyethoxy)-6,6'-dimethyl-2,2'-bipyridine (232 mg, $0.7 \mathrm{mmol}$ ) in $20 \mathrm{ml}$ ethanol, under nitrogen atmosphere, at room temperature for 2 hours. The resulted complex was obtained as intense orange/red, crystalline powder. The product was filtered and redissolved by addition of $5 \mathrm{ml}$ of deionized water followed by an addition of 10 equivalents of LiTFSI ( $37 \mathrm{mg}, 0.65 \mathrm{mmol}$ ). The solution was further stirred for 2 hours at room temperature and under nitrogen atmosphere resulting in orange/red precipitation. The 
complex was collected by filtration and washed with water. The yield of the products over $80 \%(\mathrm{~mol})$.

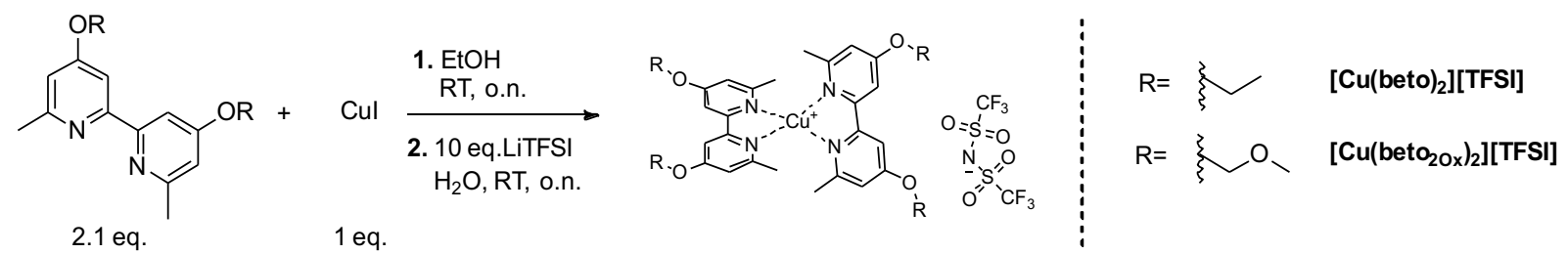

Scheme S2: Synthesis of $\left[\mathrm{Cu}(\text { beto })_{2}\right][\mathrm{TFSI}]$ and $\left[\mathrm{Cu}\left(\text { beto }_{20 x}\right)_{2}\right][\mathrm{TFSI}]$.

\section{UV-visible measurements.}

a.

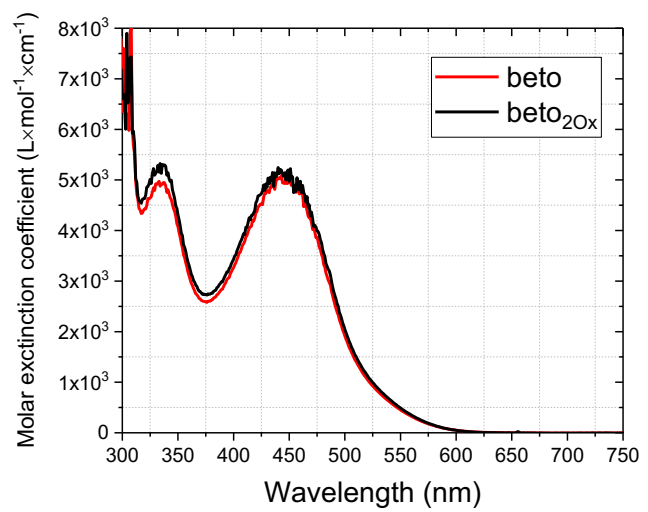

b.

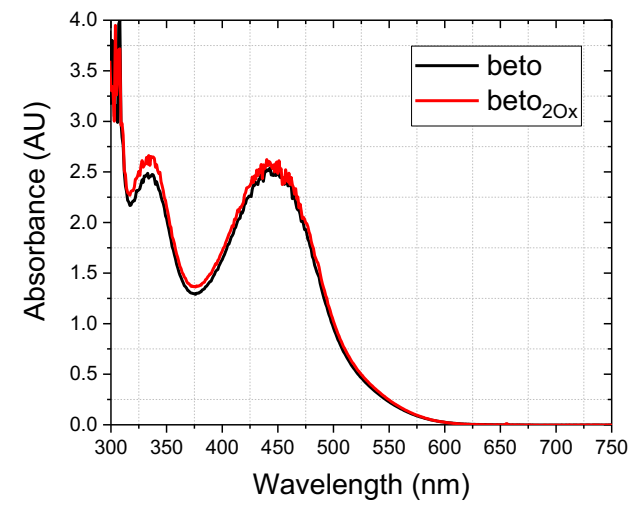

Figure S1: a)Molar extinction coefficient of [Cu(beto $\left.)_{2}\right][\mathrm{TFSI}]$ (red) and [Cu(beto $\left.\left.\left.{ }_{2}\right)_{2}\right)_{2}\right][$ TFSI](black). b) Absorption of $\left[\mathrm{Cu}(\text { beto })_{2}\right][\mathrm{TFSI}]$ (red) and [Cu(beto $\left.\left.{ }_{20}\right)_{2}\right][\mathrm{TFSI}$ (black). Measured in $0.5 \mathrm{mM} \mathrm{MeCN}$ solution. 


\section{Electrochemical measurements}

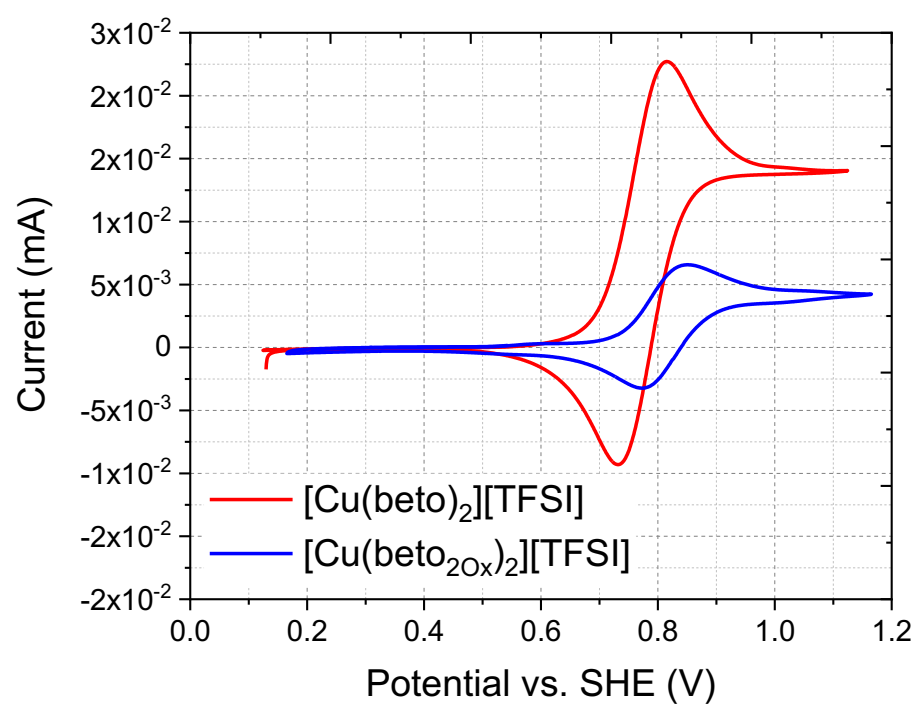

Figure S2:Cyclic voltamograms of [Cu(beto) 2$\left.][\mathrm{TFSI}]\left(\text { red) and [Cu(beto } \mathrm{O}_{2}\right)_{2}\right][\mathrm{TFSI}]($ blue). (Measured in MeCN solution containing $0.1 \mathrm{M}$ of LiTFSI as supporting electrolyte. The complexes concentrations were respectively $0.2 \mathrm{mM}$ for $\left[\mathrm{Cu}(\text { beto })_{2}\right][\mathrm{TFSI}]$ and $0.5 \mathrm{mM}$ for [Cu(beto $\left.\left.{ }_{2} \mathrm{O}_{2}\right)_{2}\right]$ [TFSI]. The electrodes consisted in a Pt disk working electrode, a Pt wire counter electrode and a $\mathrm{Ag} / \mathrm{AgCl}$ in saturated sodium chloride electrode.)

\section{X-ray diffraction}

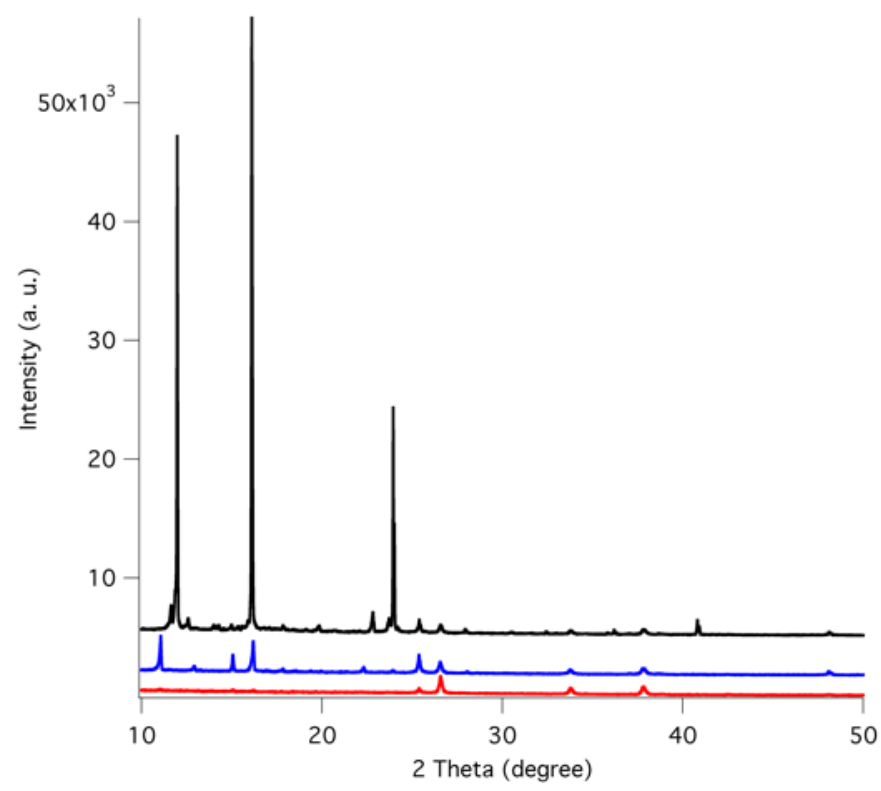

Figure S3: XRD data of the dried $\left[\mathrm{Cu}(\text { beto })_{2}\right]^{2+/ 1+}$ (blue), $\left[\mathrm{Cu}\left(\text { beto }_{2 O} \mathrm{O}_{2}\right]^{2+/ 1+}(\right.$ red $)$, and $\left[\mathrm{Cu}(\text { tmby })_{2}\right]^{2+/ 1+}$ (black) electrolytes after drop-casting on top of a $\mathrm{TiO}_{2}$ working electrode. 


\title{
6. IV data
}
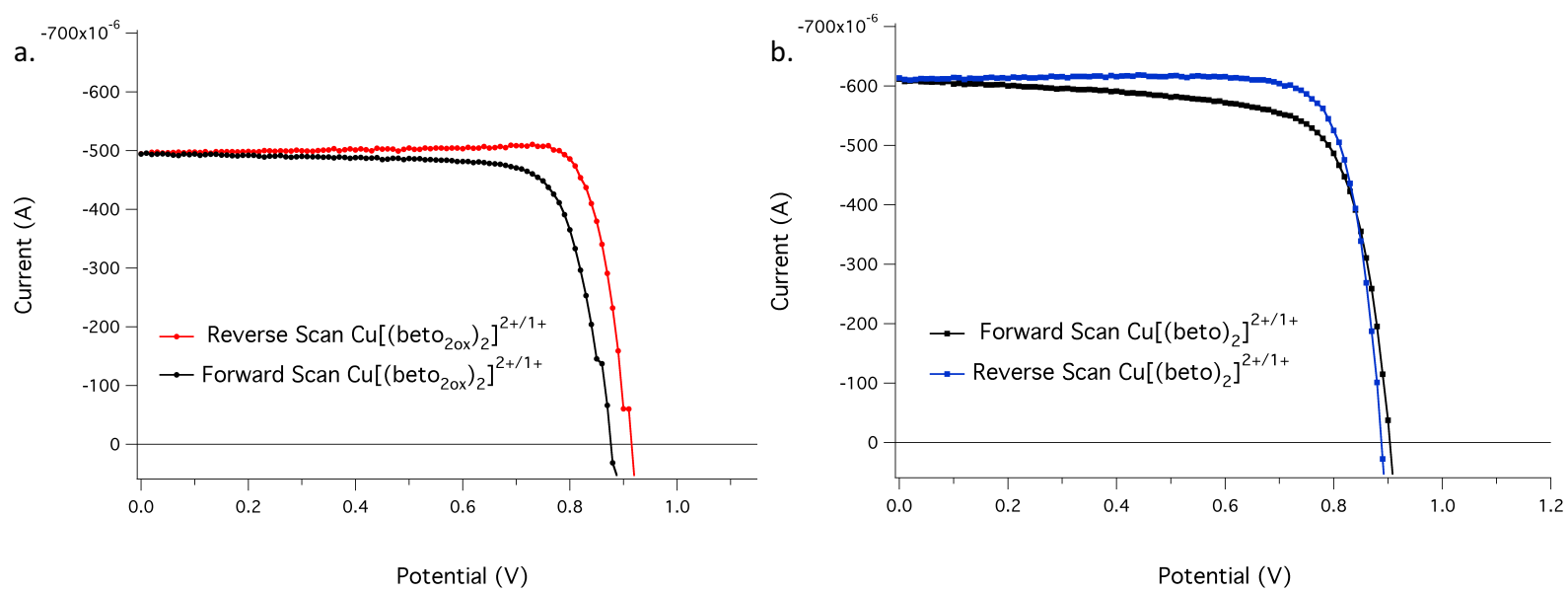

Figure S4: Hysteresis test for zombie devices employing a) $\left[\mathrm{Cu}\left(\text { beto }_{2} \mathrm{O}_{x}\right)_{2}\right]^{2+/ 1+}$ and b) $\left[\mathrm{Cu}(\text { beto })_{2}\right]^{2+/ 1+}$ complexes. (The scan settling time is 0.08 with $10 \mathrm{mV} / \mathrm{s}$ voltage steps, the measurements are carried out with, $0.16 \mathrm{~cm}^{2}$ mask).

\section{Electrochemical Impedance Spectroscopy}

\author{
Liquid state DSC
}

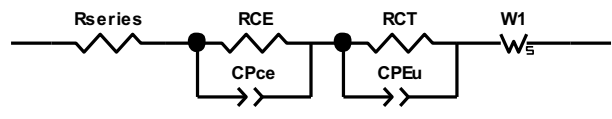

Quasi-solid state DSC

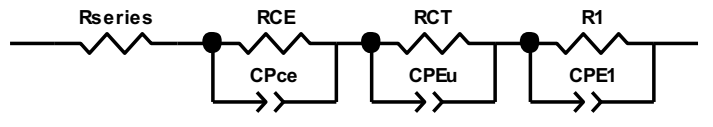

\section{Dummy cells}

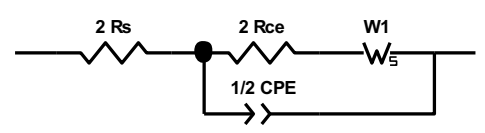

Figure S5: The equivalent circuits representing the liquid state devices, solid state devices and symmetrical dummy cells. 
Table S1: Electrochemical parameters of the studied DSC devices with $\left[\mathrm{Cu}(\text { beto })_{2}\right]^{2+/ 1+}$ and $\left[\mathrm{Cu}\left(\text { beto } 2 \mathrm{O}_{x}\right)_{2}\right]^{2+/ 1+}$ electrolytes.

\begin{tabular}{|c|c|c|c|c|}
\hline & \multicolumn{2}{|c|}{$\left[\mathrm{Cu}(\text { beto })_{2}\right]^{2+/ 1+}$} & \multicolumn{2}{|c|}{$\left[\mathrm{Cu}\left(\text { beto }_{2 \mathrm{Ox}}\right)_{2}\right]^{2+/ 1+}$} \\
\hline Device type & Liquid state & Zombie & Liquid state & Zombie \\
\hline Rseries $(\Omega)$ & 9.249 & 10.32 & 9.415 & 53.33 \\
\hline $\mathrm{R}_{\mathrm{CE}}(\Omega)$ & 4.44 & 4.567 & 3.145 & 21.08 \\
\hline CPce-T & 0.00010928 & 0.0000186 & 0.00003619 & 0.00032693 \\
\hline CPce-P & 0.9 & 0.9 & 0.9 & 0.9 \\
\hline $\operatorname{Rct}(\Omega)$ & 79.26 & 30.59 & 181.6 & 32.51 \\
\hline CPEu-T & 0.00027246 & 0.00011806 & 0.0001783 & 0.0000355 \\
\hline CPEu-P & 0.84864 & 0.76275 & 0.96491 & 0.75102 \\
\hline W1-R (R1 for zombie) & 95.99 & 287 & 69.6 & 1541 \\
\hline $\begin{array}{l}\text { W1-T(CPEu-T for } \\
\text { zombie) }\end{array}$ & 0.022155 & 0.0000999 & 0.027274 & 0.0001082 \\
\hline $\begin{array}{l}\text { W1_P(CPEu-P for } \\
\text { zombie })\end{array}$ & 0.5 & 0.93188 & 0.5 & 0.91442 \\
\hline
\end{tabular}

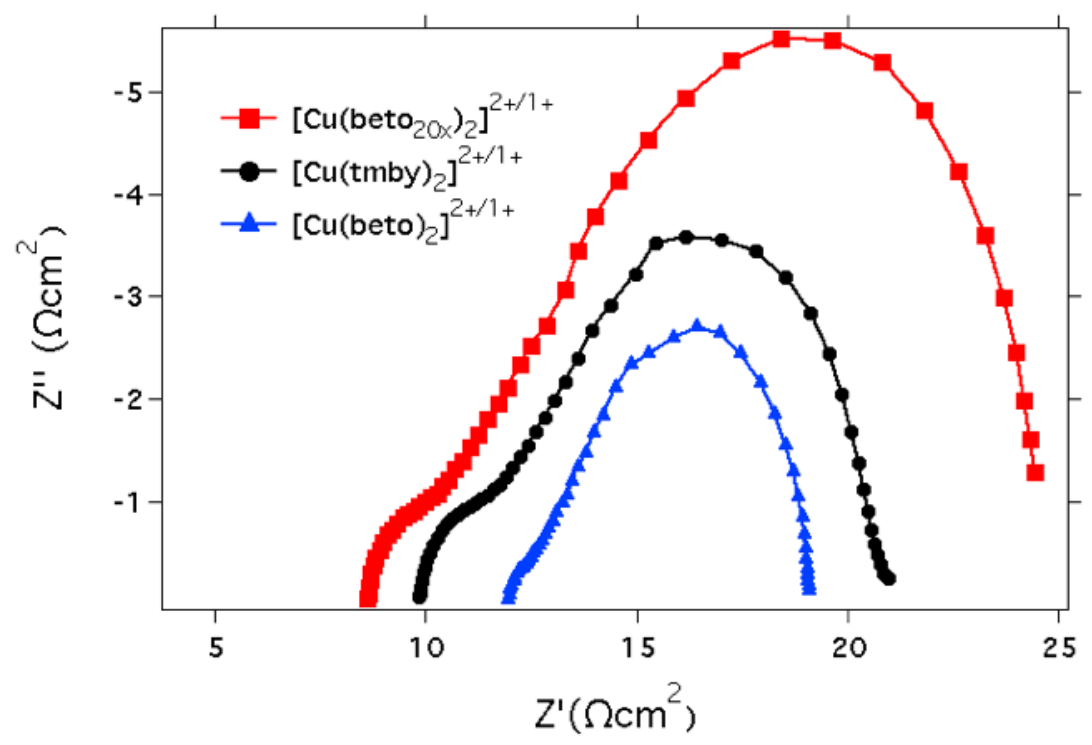

Figure S6: Nyquist plots of electrochemical impedance spectra measured at 0 V for the PEDOT/PEDOT symmetrical dummy cells. In order to avoid crossing of the curves, impedance spectra of the $\left[\mathrm{Cu}(\text { beto })_{2}\right]^{2+/ 1+}$ offset $4 \Omega \mathrm{cm}^{2}$ in the bottom axis. 